\title{
Pharmacological Update Properties of Aloe Vera and its Major Active Constituents
}

\author{
Marta Sánchez, Elena González-Burgos, Irene Iglesias and M. Pilar Gómez-Serranillos *
}

Department of Pharmacology, Pharmacognosy and Botany, Faculty of Pharmacy, Universidad Complutense de Madrid (UCM), 28040 Madrid, Spain; martas15@ucm.es (M.S.); elenagon@ucm.es (E.G.-B.); ireneig@ucm.es (I.I.)

* Correspondence: pserra@ucm.es

Received: 24 February 2020; Accepted: 11 March 2020; Published: 13 March 2020

\begin{abstract}
Aloe vera has been traditionally used to treat skin injuries (burns, cuts, insect bites, and eczemas) and digestive problems because its anti-inflammatory, antimicrobial, and wound healing properties. Research on this medicinal plant has been aimed at validating traditional uses and deepening the mechanism of action, identifying the compounds responsible for these activities. The most investigated active compounds are aloe-emodin, aloin, aloesin, emodin, and acemannan. Likewise, new actions have been investigated for Aloe vera and its active compounds. This review provides an overview of current pharmacological studies (in vitro, in vivo, and clinical trials), written in English during the last six years (2014-2019). In particular, new pharmacological data research has shown that most studies refer to anti-cancer action, skin and digestive protective activity, and antimicrobial properties. Most recent works are in vitro and in vivo. Clinical trials have been conducted just with Aloe vera, but not with isolated compounds; therefore, it would be interesting to study the clinical effect of relevant metabolites in different human conditions and pathologies. The promising results of these studies in basic research encourage a greater number of clinical trials to test the clinical application of Aloe vera and its main compounds, particularly on bone protection, cancer, and diabetes.
\end{abstract}

Keywords: Aloe vera; pharmacology; extracts; isolated compounds

\section{Introduction}

Aloe vera (Aloe barbadensis Miller, family Xanthorrhoeaceae) is a perennial green herb with bright yellow tubular flowers that is extensively distributed in hot and dry areas of North Africa, the Middle East of Asia, the Southern Mediterranean, and the Canary Islands. Aloe vera derives from "Allaeh" (Arabic word that means "shining bitter substances") and "Vera" (Latin word that means "true"). The colorless mucilaginous gel from Aloe vera leaves has been extensively used with pharmacological and cosmetic applications. Traditionally, this medicinal plant has been employed to treat skin problems (burns, wounds, and anti-inflammatory processes). Moreover, Aloe vera has shown other therapeutic properties including anticancer, antioxidant, antidiabetic, and antihyperlipidemic. Aloe vera contains more than 75 different compounds, including vitamins (vitamin A, C, E, and B12), enzymes (i.e., amylase, catalase, and peroxidase), minerals (i.e., zinc, copper, selenium, and calcium), sugars (monosaccharides such as mannose-6-phosphate and polysaccharides such as glucomannans), anthraquinones (aloin and emodin), fatty acids (i.e., lupeol and campesterol), hormones (auxins and gibberellins), and others (i.e., salicylic acid, lignin, and saponins) [1-3].

In this review, we summarize an update of the pharmacological activities (in vitro, in vivo, and clinical trials) of Aloe vera. Publications (original papers) were published in English in the years 2014 to 2019 in peer-reviewed scientific journals of the Pubmed database. Those articles that included Aloe vera combined with other plants or Aloe species other than Aloe vera were excluded from this review. 
This review is structured into different activities, which include in vitro, in vivo, and clinical trials, published in the last six years. The order of activities is based on the interest and importance of studies for Aloe vera. The Table 1 (in vitro studies), Table 2 (in vivo studies), and Table 3 (clinical trials) summarize the main pharmacological findings for Aloe vera and its isolated compounds (Figures 1 and 2).<smiles>O=C1c2cccc(O)c2C(=O)c2c(O)cc(CO)cc21</smiles>

Aloe emodin<smiles>CC(=O)Cc1cc(=O)c2c(C)cc(O)c([C@@H]3O[C@H](CO)[C@@H](O)[C@H](O)C3O)c2o1</smiles>

Aloesin

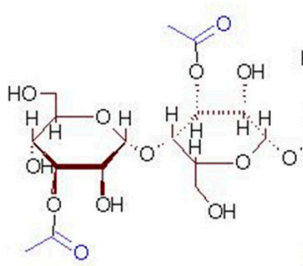
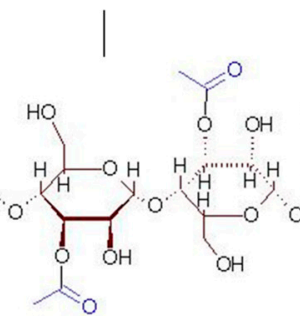

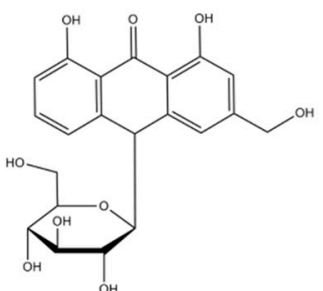

Aloin / Barbaloin<smiles>Cc1cc(O)c2c(c1)C(=O)c1cc(O)cc(O)c1C2=O</smiles>

$\aleph_{0}=$ Acetyl group

\section{Acemannan}

Figure 1. Chemical structure of compounds isolated from Aloe vera with pharmacological activity.

\begin{abstract}
Digestive diseases protection Acemannan
\end{abstract}

Antidiabetic effect
$\begin{gathered}\text { Aloe-emodin } \\ \text { Aloin }\end{gathered}$

Cardioprotective effect Aloe-emodin

Skin protection Aloe-emodin Aloesin

Aloin Emodin
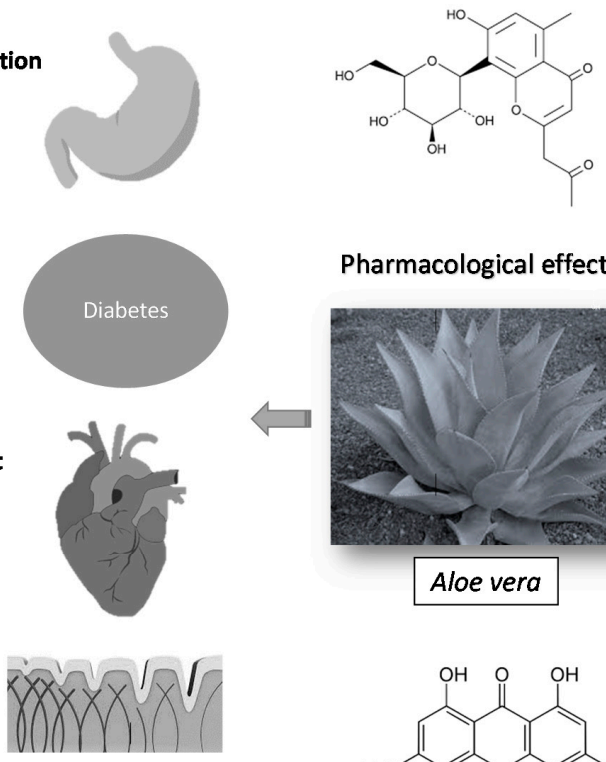

Pharmacological effects

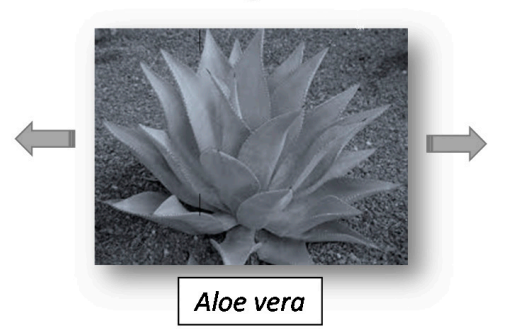
and Prebiotic activity

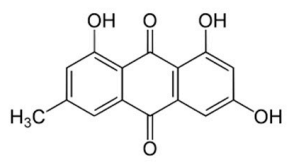

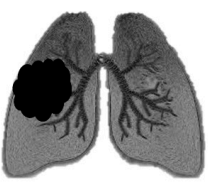

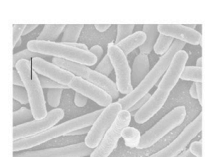

Acemannan Aloe-emodin

Bone protection

Aloe-emodin Aloin

Anti-cancer effects

Aloe-emodin

Aloin

Aloesin

Emodin

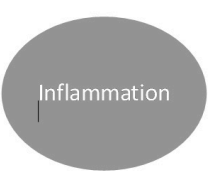

Skin protection

Acemannan Aloe-emodin Aloin

Figure 2. Pharmacological effects of the main constituents of Aloe vera. 


\section{Digestive Diseases Protection}

Aloe vera extract $(50 \%)$ increased cell viability of dental pulp stem cells being useful for avulsed broken teeth [4]. This effect is attributed to polysaccharides, mainly acemannan, by inducing osteogenic-specific gene expressions, DNA synthesis, growth factor, and JAK-STAT pathway $[5,6]$. Moreover, Aloe vera $(225 \mathrm{mg} / \mathrm{kg})$ exerted a radioprotective effect against salivary gland dysfunction in a rat model as evidenced in an increase of salivary flow rate [7].

Periodontitis is a serious and common dental affliction in which gums are infected and become inflamed, causing tissue and bone destruction. Gingivitis is the initial phase of periodontitis and is caused by dental plaque. Significant clinical evidence has demonstrated that Aloe vera mouthwash and gel are effective in the prevention and treatment of gingivitis and periodontitis by reducing gingival index, plaque index, and probing depth and by increasing bone fill and regeneration [8-14]. Aloe vera has proven to be as effective as other usual treatments such as chlorhexidine, alendronate, and chlorine dioxide $[8,10,11,13]$.

In a randomized placebo double-blind study with 20 healthy adults, Fallahi et al. [15] investigated the effect of Aloe vera mouthwash on postoperative complications after impacted third molar surgery. Aloe vera gel significantly reduced swelling and postoperative pain. In another work, Kalra et al. [16] evaluated the efficacy of Aloe vera gel and mineral trioxide aggregate as pulpotomy agents in primary molar teeth. The overall success rates at 3, 6, 9, and 12 months was high for patients treated with mineral trioxide aggregate. Moreover, a cross-sectional randomized interventional study revealed that Aloe vera gel promoted wound healing and reduced pain in patients that required atraumatic tooth extractions, and its effectiveness was higher than that of traditional analgesics [17]. Furthermore, Aloe vera resulted to be a promising cavity disinfecting agent in minimally invasive dentistry in a randomized clinical trial with 10 patients [18].

Oral mucositis/stomatitis is an inflammatory and/or ulcerative condition that occurs as a debilitating complication of chemotherapy and radiotherapy treatments and affects quality of life of oncological patients. Aloe vera mouthwash alleviated radiation-induced mucositis severity in patients with head and neck cancers similarly to the reference benzydamine mouthwash [19]. Moreover, Aloe vera mouthwash has also demonstrated to be efficient in the treatment of stomatitis (mean intensity and pain) associated with radiotherapy in patients with acute myeloid leukemia and acute lymphocytic leukemia [20].

Oral submucous fibrosis is a precancerous condition of the oral cavity characterized by abnormal collagen deposition. This malignant disorder is mainly caused by chewing areca nut and it is most frequent in India and Southeast Asia. Anuradha et al. [21] evaluated the efficacy of Aloe vera (systemic as juice and topical as gel) in the treatment of oral submucous fibrosis. Clinical evidence demonstrated that Aloe vera reduced burning sensation and increased cheek flexibility, mouth opening, and tongue protrusion similar to the reference treatment hydrocortisone, hyaluronidase, and antioxidant supplements. In another study on oral submucous fibrosis, the combination of Aloe vera gel with physiotherapy was more efficient in decreasing burning sensation and increasing tongue protrusion, mouth opening, and cheek flexibility than the combination of antioxidant capsules with physiotherapy [22].

Gastroesophageal reflux disease is a common chronic digestive disease in which gastric acids move up into the esophagus. Aloe vera syrup ( $10 \mathrm{~mL} /$ day) for 4 weeks reduced the frequency of symptoms of gastroesophageal reflux diseases including heartburn, food regurgitation, dysphagia, flatulence, belching, nausea, and acid regurgitation without causing adverse effects (only one case of vertigo and another of stomach ache were reported) [23].

Gastritis is an inflammation of mucous membrane layer of the stomach. Aloe vera gel protected in a Balb/c mouse model of alcohol-induced acute gastritis by increasing matrix metalloproteinase- 9 inhibitory activity [24].

The topical administration of Aloe vera 3\% ointment alleviated the symptoms of diarrhea and fecal urgency in patients with acute radiation proctitis induced by radiotherapy of the pelvic 
area [25]. Moreover, Aloe barbadensis extract $\left(\mathrm{AVH} 200^{\circledR}\right)$ reduced, but not significantly, the severity of gastrointestinal symptoms in patients with irritable bowel syndrome compared to a control group [26]. Lin et al. [5] revealed that Aloe polysaccharide $(15 \mathrm{mg} / \mathrm{kg})$ protected rats from 2,4,6-three nitrobenzene sulfonic acid colitis induced by increasing JAK2, p-JAK2, STAT-3, and p-STAT3 protein expression. Furthermore, Aloe vera cream applied three times daily for 6 weeks reduced chronic anal fissure pain and hemorrhaging after defection and promoted wound healing in a prospective double blind clinical trial [27].

\section{Skin Protection}

Most in vitro studies on skin protection study the ability of Aloe vera and active compounds in wound healing. The immortalized human keratinocyte HaCaT cell line, the primary normal human epidermal keratinocytes HEKa cell line, and fibroblasts cell lines are the most used. These studies have revealed that Aloe vera and its major compounds (aloesin, aloin, and emodin) exert their protective action mainly through antioxidant and anti-inflammatory mechanisms. Hence, Aloe vera up-regulated TFG $\beta 1$, bFGF, and Vegf-A expression in fibroblasts and increased keratinocyte proliferation and differentiation by lysosomal membrane stability [28-32]. Moreover, Aloe vera solution could accelerate corneal wound closure at low concentrations $(\leq 175 \mu \mathrm{g} / \mathrm{mL})$ by increasing type IV collagen-degrading activity in a cellular model of primary cultures of corneal epithelial cells [33]. Furthermore, aloin exerted skin protection by reducing IL-8 production, DNA damage, lipid peroxidation, and ROS generation and by increasing GSH content and SOD activity [34]. The compound aloesin resulted in promoting wound healing by increasing cell migration via phosphorylation of Cdc42 and Rak1, cytokines, and growth factors [35]. In addition to this healing activity, it has been seen that Aloe polysaccharide $(20,40$, and $80 \mu \mathrm{g} / \mathrm{mL}$ for $24 \mathrm{~h}$ ) could be a beneficial agent in psoriasis as evidenced in the inhibition of TNF- $\alpha$ levels and IL-8 and IL-12 protein expression in human keratinocyte HaCaT cell line.

As for in vivo studies, the most common models are genetically modified animals (BALB/c mice, HR-1 hairless mice and SKH-1 hairless mice) and UV and X-ray skin damage in animals. Most of these in vivo studies have been done with Aloe vera extracts and gel. Application of topical Aloe vera favored wound healing in animal models with dermal incisions by reducing inflammatory cell infiltration, increasing CD4+/CD8+ ratio lymphocytes, and improving epidermal thickness and collagen deposition [36-39]. In another study conducted in Indonesia with several medicinal plants, the effect of Nigella sativa oil gel and Aloe vera gel to treat diabetic ulcers was investigated. Aloe vera resulted to be more efficient in improving wound healing on alloxan-induced diabetes in Wistar rats with wounds on dorsum as evidenced by a decrease of necrotic tissue and inflammation and an improvement of re-epithelialization [40]. Furthermore, a UV-induced mice model revealed that Aloe vera gel powder increased epidermal growth factor and hyaluronan synthase and reduced matrix metalloproteinases expression (types 2, 9, and 13) [41,42]. Aloe sterols are involved in this UV protection [43]. Likewise, it has been observed that Aloe vera protected against X-radiation through antioxidant mechanisms (increased antioxidant enzyme activity and GSH content and reduced ROS production and lipid peroxidation) [44,45]. Among isolated compounds, investigations with the compounds aloe-emodin and aloesin have shown that their healing activity is due to angiogenic properties [46,47].

In the last 6 years, several clinical trials have also been carried out. Some of these have been aimed at evaluating the effectiveness of Aloe vera on ulcers. Hence, the administration of Aloe vera gel twice daily for 3 months improved and accelerated wound healing as well as reduced hospitalization time $[48,49]$. Moreover, in a randomized, triple-blind clinical trial with 80 patients hospitalized in the orthopedic ward, Hekmatpou et al. [50] demonstrated that Aloe vera gel twice daily for 10 days prevented the development of pressure ulcers on the areas of hip, sacrum, and heel. Moreover, clinical trials have demonstrated that Aloe vera facilitated rapid tissue epithelialization and granulation in burns [51], promoted healing of cesarean wound [52], and accelerated wound healing of split-thickness skin graft donor sites [53]. Furthermore, Aloe vera has been investigated in randomized, double-blind, 
placebo-controlled studies for its benefits to maintain healthy skin. Therefore, the daily oral intake of $40 \mu \mathrm{g}$ of Aloe sterol (cycloartenol and lophenol) for at least 12 weeks improved skin elasticity in men under 46 years exposed to the sunlight but do not use sunscreen to protect themselves [54], reduced facial wrinkles in Japanese women over 40 years old by stimulating hyaluronic acid and collagen production [55], and increased gross elasticity, net elasticity, and biological elasticity in women aged 30-59 [56]. However, despite clinical evidence on the protective role of Aloe vera in the skin, there are clinical trials that have not yet found effectiveness of this medicinal plant, particularly in decreasing radiation-induced skin injury. Two clinical trials have been published between 2014 and 2019 in relation to this effect. Both studies found that topical administration of Aloe vera as gel or cream did not reduce the prevalence and severity of radiotherapy-induced dermatitis and skin toxicity in breast cancer patients compared to control group $[57,58]$.

\section{Anti-Inflammatory Activity}

Most recent studies on anti-inflammatory activity of Aloe vera are focused on the action mechanism of isolated compounds in murine macrophage RAW264.7 cells and mice stimulated with LPS. Hence, the potential anti-inflammatory effect of aloin is related to its ability to inhibit cytokines, ROS production, and JAK1-STAT1/3 signaling pathway [59,60]. Moreover, aloe-emodin sulfates/glucuronides $(0.5 \mu \mathrm{M})$, rhein sulfates/glucuronides $(1.0 \mu \mathrm{M})$, aloe-emodin $(0.1 \mu \mathrm{M})$, and rhein $(0.3 \mu \mathrm{M})$ inhibited pro-inflammatory cytokines and nitric oxide production, iNOS expression, and MAPKs phosphorylation [61].

In another study, Thunyakitpisal et al. [62] demonstrated that acemannan increased IL-6 and IL-8 expression and NF- $\mathrm{KB} / \mathrm{DNA}$ binding in human gingival fibroblast via a toll-like receptor signaling pathway. Since there is a relation between high IL-1 $\beta$ levels and periodontal diseases, Na et al. [63] investigated the anti-inflammatory properties of aloin in human oral KB epithelial cells stimulated with saliva from healthy volunteers. This study revealed that those saliva samples with high content in IL-1 $\beta$ stimulated IL-8 production in KB cells, and pretreatments with aloin inhibited IL-8 production by decreasing p38 and extracellular signal-regulated kinases pathway.

In addition to isolated compounds, Ahluwalia et al. [64] evaluated the activity of AVH200 ${ }^{\circledR}$, a standardized Aloe vera extract which contains alin and acemannan on the activation, proliferation, and cytokine secretion of human blood $\mathrm{T}$ cells obtained from healthy individuals aged 18-60, and they found that it decreased CD25 and CD3 expression on CD3(+) T cells. Moreover, AVH200 ${ }^{\circledR}$ exhibited concentration-dependent $\mathrm{T}$ cell proliferation suppression and IL-2, IFN- $\gamma$, and IL-17A reduction. Moreover, the anti-inflammatory effect of Aloe vera has also been investigated in an acetaminophen-induced hepatitis (inflammatory condition of the liver) mice model. The results of this study revealed that Aloe vera $(150 \mathrm{mg} / \mathrm{kg}$ ) reduced hepatic MDA, IL-12, and IL-18 levels and ALT and increased GSH content [65].

\section{Anticancer Effects}

Studies conducted in the years of the review of this work focusing on cancer are mostly in vitro and in vivo studies. In vitro studies have the main purpose of identifying potential molecules with cytotoxic activity for later evaluation in in vivo studies and clinical trials. In addition, in vitro studies allow elucidating the mechanism of action by identifying promising pharmacological targets. In vivo studies allow us to understand the pharmacological activity and behavior in living organisms prior to their study in humans. Since clinical trials are very limited, and as it is not possible to confirm the anti-cancer activity of Aloe vera and its bioactive principles, it would be interesting for future research to focus on this activity based on the promising in vitro and in vivo results.

In vitro and in vivo studies included in the present review are aimed at evaluating cytotoxic and antitumor activity against a variety of cancer types using a diversity of cell lines and animal models (breast and gynecological cancers such as cervical cancer and ovarian cancer, malignant conditions of the gastrointestinal tract (i.e., oral cavity, esophagus, colon) and accessory digestive organs (pancreas), 
osteosarcomas, and melanoma). One clinical trial focused on the efficacy of Aloe vera on ocular surface squamous neoplasia; this clinical trial has been included at the end of this section.

MCF-7 cells, which express estrogen receptor, are the most popular breast cancer cell line, and the immortal HeLa cell line are the oldest and most used cervical cancer cells [66,67]. Aloe vera crude extracts $(40 \%, 50 \%$, and $60 \%$ for 6,24 , and $48 \mathrm{~h}$ ) reduced cell viability of cancer cell lines (human breast MCF-7 and cervical HeLa) through apoptosis induction (chromatin condensation and fragmentation and apoptotic bodies appearance in sub-G0/G1 phases) and modulation of effector genes expression (an increase in cyclin D1, CYP1A1, and CYP1A2 expression and a decrease in p21 and bax expression) [68]. Moreover, the isolated compound aloe-emodin has resulted to be an effective anticancer agent against both MCF-7 cells and HeLa cells by inducing mitochondrial and endoplasmic reticulum apoptosis and inhibiting metastasis oxidative stress [69-72]. Furthermore, a recent study demonstrated that Aloe vera extract $(300 \mathrm{mg} / \mathrm{kg}$ ) and training (swimming) combined exerted a protective anticancer effect in mice with breast cancer by inhibiting the COX pathway (COX-2 reduction levels) and prostaglandin E2 production [73]. Finally, aloesin reduced tumor growth in in vitro and in vivo models of ovarian cancers by inhibiting the MAPK signaling pathway [74].

For malignant conditions of gastrointestinal tract and accessory digestive organs, emodin (10, 20, 30, $40 \mu \mathrm{M}$ for 24 and $48 \mathrm{~h}$ ) decreased cell proliferation and Bcl-2 protein levels and increased caspase-3 protein expression and Bax protein levels in human oral mucosa carcinoma KB cells [75]. Moreover, aloe-emodin has been shown to effectively suppress esophageal TE1 cancer cells in a concentration-dependent manner (from $2.5 \mu \mathrm{M}$ to $20 \mu \mathrm{M}$ concentrations assayed) through inhibiting AKT and ERK phosphorylation and reducing the number of cells in the $S$ phase [76]. Furthermore, Aloe polysaccharide induced autophagy alone and in combination with radiation in pancreatic carcinoma BxPC-3 cells as evidenced in ULK1 mRNA expression upregulation and BECN1 and BCL-2 mRNA expression downregulation [77]. Finally, several in vitro and in vivo studies were performed to evaluate the potential anticancer properties of Aloe vera and its isolated compounds in colon cancer (fourth most common cancer and the third leading death cause) [78]. Chen et al. [79] exhibited cytotoxic properties of aloe-emodin on colon cancer cells at 10,20 , and $40 \mu \mathrm{M}$ concentrations through activating the apoptotic pathway, increasing ROS production, and cytosolic calcium levels and up-regulating ER stress-related proteins. Moreover, Aloe vera powder and extract $1 \%$ and 3\% protected C57BL/6J mice from aberrant crypt foci colorectal cancer by increasing hepatic phase II enzyme glutathione S-transferase mRNA levels [80]. Furthermore, Aloe vera gel (200 or $400 \mathrm{mg} / \mathrm{kg} / \mathrm{day}$ orally) reduced inducible NO synthase and COX2 expression, NF-kB activation, and cell cycle progression, inducing cellular factors in BALB/c female mice with induced colitis-associated colon carcinogenesis.

Osteosarcomas are uncommon bone tumors in which malignant cells produce osteoid [81]. Aloe-emodin has also resulted to be a promising photosensitive agent against the human osteosarcoma MG-63 cell line via ROS/JNK signaling pathway as evidenced in an increase of caspases, cytochrome c, CHOP, and GRP78 expression [82,83].

For melanoma (malignant transformation of melanocytes), aloe-emodin protected against metastatic human melanoma cells by decreasing cell proliferation, increasing cell differentiation, and transamidating activity of transglutaminase and dabrafenib antiproliferative activity [84,85].

Regarding clinical trials conducted in recent years on anticancer activity, Damani et al. [86] reported the efficacy of Aloe vera eye drops 3 times daily for 3 months in the regression of ocular surface squamous neoplasia in a 64-year-old Hispanic woman. On the other hand, Koo et al. [87] stated that aloe polysaccharide could reduce tobacco associated diseases such as cancer due to its ability to increase urinary excretion of benzo(a)pyrene and cotinine.

\section{Antidiabetic Effect}

Diabetes is a chronic disease presenting with high levels of glucose in blood because of an insulin resistance or an insulin deficiency. Studies on the effect of Aloe vera in diabetes and related complications have been investigated mainly in animal models induced by streptozotocin. Consistent 
evidence supports that oxidative stress is a main cause of the beginning and the progression of diabetes complications such as nephropathies and neuropathies. Hence, using this experimental model, Aloe vera showed to reduce blood glucose levels, to increase insulin levels, and to improve pancreatic islets (number, volume, area, and diameter) [88], and this medicinal plant protected from oxidative stress-induced diabetic nephropathy and anxiety/depression-like behaviors [89]. Moreover, Aloe vera topical administration $(60 \mathrm{mg} / \mathrm{mL}$, four times daily for 3 days of eye drops) favored corneal re-epithelialization in streptozotocin-induced diabetic Wistar rats with corneal alkali burn injury [90]. Furthermore, experiments with genetically modified animals have revealed that Aloe vera polysaccharides (100 $\mu \mathrm{g} / \mathrm{g}$ for 3 weeks) are responsible for the decrease of blood glucose levels [91]. A recent in vitro study showed that the action mechanism of Aloe vera polysaccharides antidiabetic effect is related to its ability to inhibit apoptosis and endoplasmic reticulum stress signaling [91]. In another in vitro study using a high-glucose-induced toxicity cell model, the compound aloe-emodin $(20 \mu \mathrm{M})$ protected RIN-5F cells derived from rat pancreatic $\beta$-cells from glucotoxicity through an apoptotic and anti-inflammatory effects [92]. Lastly, the intake of Aloe vera (300 mg twice day for 4 weeks) decreased fasting blood glucose in pre-diabetic subjects [93].

\section{Antioxidant Properties}

Antioxidants are compounds that prevent or slow down biomolecule oxidative damage caused by ROS through free radical scavenging, metal chelation, and enzyme regulation [94]. Kumar et al. 2017 [95] investigated the potential antioxidant activity of crude methanolic extracts of Aloe vera from six agro-climatic zones of India using different in vitro methods (i.e., DPPH, metal chelating, and reducing power assay). Antioxidant activity was higher in those species collected in Northern India than in Southern India, which is related to a high content in alkaloids, glycosides, phenolic compounds, flavonoids, and saponin glycosides. Moreover, Aloe vera ethanol extract protected, particularly human microvascular endothelial cells, against hydrogen peroxide and 4-hydroxynonenal-induced toxicity by reducing ROS production and HNE-protein adducts formation [96]. The antioxidant activity of Aloe vera is, at least in part, due to anthraquinones and related compounds $(10 \mu \mathrm{M})$ which possess peroxyl radical scavenging activity and reducing capacity [97].

Apart from these in vitro assays, in a clinical trial with 53 healthy volunteers, the intake of Aloe vera gel extract (14 days) increased total antioxidant capacity of plasma of subjects [98].

\section{Bone Protection}

In vitro studies with isolated Aloe vera compounds have been aimed at studying the potential protective effect on bone pathogenesis. Aloe-emodin induced chondrogenic differentiation on clonal mouse chondrogenic ATDC5 cells which is related to bone formation through BMP-2 and MAPK-signaling pathway activation [99]. Moreover, aloin has resulted to be beneficial in osteoporosis and osteopenia disorders by suppressing receptor activator of NFkB ligand (RankL) induced through NF- $\mathrm{KB}$ inhibition in mouse macrophage RAW 264.7 cells [100,101].

\section{Cardioprotective Effect}

In vivo models of ischemia-reperfusion injury are commonly employed to evaluate the cardioprotective activity of Aloe vera. Aloe vera administered with gastric gavage previous to abdominal aorta and spinal cord ischemia increased antioxidant enzymes activity (SOD, CAT, and GPx) and reduced lipid peroxidation level (MDA content), edema, hemorrhage, and inflammatory cell migration in Wistar albino rats [102,103]. Moreover, barbaloin, also known as aloin, $(20 \mathrm{mg} / \mathrm{kg} / \mathrm{day}$, 5 days) administered intragastrically reduced myocardial oxidative stress and inflammatory response and increased AMPK signaling in Sprague-Dawley rats in a myocardial ischemia/reperfusion injury [104]. Esmat et al. [105] demonstrated that this compound $(50 \mathrm{mg} / \mathrm{kg}$ body weight, twice weekly over 2 weeks), administered intramuscularly, had non-atherogenic activity and iron chelating properties. Another compound isolated from Aloe vera and investigated for its cardioprotective 
properties is aloe-emodin. In an in vitro model of heme protein (hemoglobin), it was demonstrated that aloe-emodin $(100 \mu \mathrm{M})$ had its maximum activity as an anti-aggregatory agent as evidenced in structural alterations of $\beta$ sheet and the appearance of $\alpha$ helices [106]. On the other hand, an in vivo study revealed that aloe-emodin could alleviate hyperlipidemia by reducing total cholesterol and low-density lipoprotein-cholesterol levels at doses of 50 and $100 \mathrm{mg} / \mathrm{kg}$ for 6 weeks in male Wistar rats [107]. Regarding clinical studies, a double-blind randomized controlled trial showed that Aloe vera $300 \mathrm{mg}$ and $500 \mathrm{mg} /$ twice day for 4 and 8 weeks reduced $\mathrm{HbA1C}$, total cholesterol, LDL, and triglyceride levels in pre-diabetic patients [92]. Furthermore, the oral gavage administration of Aloe vera (30 mg/kg/day for 1 month) resulted to decrease ischemic fiber degeneration by preventing the formation of lipid peroxides, increasing antioxidant enzymes, and up-regulating the transcription factor NRF1 in Wistar albino rats [108].

\section{Antimicrobial and Prebiotic Activity}

Different studies have been carried out to evaluate the antimicrobial activity of Aloe vera and its main constituents. Most of these studies are in vitro and focus on the antibacterial activity. One of the most studied bacteria are Staphlococcus aureus and Pseudomonas aeruginosa. Hence, Aloe vera aqueous extract reduced growth and biofilm formation against methicillin resistant Staphylococcus aureus [109]. Moreover, this bacteria has also been inhibited by Aloe vera gel (50\% and $100 \%$ concentrations), along with other oral pathogens obtained from patients with periapical and periodontal abscess including Actinobacillus actinomycetemcomitans, Clostridium bacilli, and Streptococcus mutans using disc diffusion, micro-dilution, and agar dilution methods [110]. One of the compounds attributed to antibacterial activity against Staphylococcus aureus is aloe-emodin which acts by inhibiting biofilm development and extracellular protein production [111]. In the case of Pseudomonas aeruginosa, Aloe vera extracts have shown to inhibit the growth of multidrug-resistant Pseudomonas aeruginosa isolated from burned patients with wounds infections at $\mathrm{MIC}_{50}$ and $\mathrm{MIC}_{90}$ values of $200 \mu \mathrm{g} / \mathrm{mL}$ [112]. Pseudomonas aeruginosa growth and biofilm formation inhibition has been also demonstrated for Aloe vera inner gel. This Aloe vera inner gel also inhibited other Gram-negative bacteria (Helicobacter pylori and Escherichia coli) as well as the fungus Candida albicans [113]. Moreover, in another study, Aloe vera hydroalcoholic extract showed antibacterial activity against Enterococcus faecalis, an infecting microorganism of the root canals of teeth, with inhibition zones of $13 \mathrm{~mm}$ (saturated) and $9.6 \mathrm{~mm}$ (diluted) [114]. Furthermore, concentrations up to $1 \mathrm{mg} / \mathrm{mL}$ of Aloe vera aqueous extracts could inhibit Mycobacterium tuberculosis growth, which is the pathogen responsible for causing tuberculosis, one of the most lethal infectious diseases worldwide [115]. Finally, in a clinical trial with 53 healthy volunteers, the daily drinking of Aloe vera gel extract for 14 days exerted an antimicrobial activity as shown in a reduction of Lactobacillus spp. number [98].

Antiviral activity of Aloe vera has been investigated for herpes simplex virus type 1 and H1N1 subtype influenza virus. Aloe vera extract gel (concentrations from $0.2 \%$ to $5 \%$ ) showed antiviral activity against herpes simplex virus type 1 on Vero cells by inhibiting its growth [116]. On the other hand, in vitro studies have demonstrated that Aloe polysaccharides decreased H1N1 subtype influenza virus replication and viral adsorption period by interacting with influenza virus particles. Moreover, in vivo studies with SPF BALB/c mice infected with PR8(H1N1) improved clinical symptoms and lung damage [117].

The parasite Plasmodium falciparum is the main causative agent of malaria, in its most aggressive and lethal form. Kumar et al. [118] investigated the activity of Aloe vera crude aqueous extracts collected in six different climatic regions of India (highland, semi-arid, arid, humid subtropical, tropical wet and dry, and humid subtropical climate) against a chloroquine-sensitive strain of Plasmodium falciparum. This study showed that those Aloe vera from colder climatic regions possessed the highest antiplasmodial activity which was related to the highest aloin and aloe-emodin content (EC50 value of $0.289 \mu \mathrm{g} / \mathrm{mL})$. 
Finally, there are other studies which support the prebiotic potential of Aloe vera defined as "a substrate that is selectively utilized by host microorganisms conferring a health benefit". Aloe vera mucilage (rich in acemannan) could improve gastrointestinal health by increasing short chain fatty acids and modifying bacterial composition [119]. Moreover, acemannan and fructans from Aloe vera increased bacterial growth, especially Bifidobacterium spp. population [120].

\section{Other Effects}

Aloe vera has also been investigated for treating reproductive health care problems. The results of these works carried out with experimental animals are contradictory. While Asgharzade et al. [121] demonstrated that Aloe vera ethanol extract (150 and $300 \mathrm{mg} / \mathrm{kg}$ ) had negative effects on spermatogenesis and sperm quality in Wistar rats, Erhabor and Idu [122] observed that Aloe vera ethanol extract $(400 \mathrm{mg} / \mathrm{kg}$ ) improved male sexual behavior (mount frequency and latency, intromission frequency and latency, and testosterone levels) and Behmanesh et al. [123] that Aloe vera extract increased body and testis weights, spermatocyte and spermatids quantity, and seminiferous tubule diameter and height.

Aloe vera processed gel prevented of ovoalbumin-induced food allergy by exerting an anti-inflammatory action (histamine, mast cell protease-1, and IgE reduction) [124].

At the blood level, the oral administration of Aloe vera gel prevented and restored lymphopenia and erythropenia as well as IgA secretion on cyclophosphamide-induced genetically modified mice [125]. Moreover, Aloe vera ethanol extract $(200 \mathrm{mg} / \mathrm{kg}, 400 \mathrm{mg} / \mathrm{kg}$, and $600 \mathrm{mg} / \mathrm{kg})$ normalized levels of white blood cells, red blood cells, and platelet count through antioxidant mechanisms [126].

Regarding diseases of the musculoskeletal system, aloe-emodin showed to reduce viable cell numbers (concentrations $\geq 10 \mu \mathrm{M}$ ) and to induce apoptosis by arresting G2/M phase (concentrations $\geq 20 \mu \mathrm{M}$ ) in MH7A human synovial fibroblast-like cells, aloe-emodin being a promising agent to treat rheumatoid arthritis and a complementary treatment to methotrexate [127]. Moreover, Aloe vera lyophilized extract ointment reduced tendon lesions and increased non-collagenous proteins in Wistar rats with partial transection of the calcaneal tendon [128].

The dose of $10 \mathrm{mg} / \mathrm{kg}$ of Aloe vera aqueous extract (3 times daily for a week) resulted to be the most effective in morphine withdrawal syndrome in morphine-dependent female rats as shown in agitation, disparity, and floppy eyelids reduction [129].

Finally, highlighting the protective effect of Aloe vera gel extract (seven weeks, $500 \mathrm{mg} / \mathrm{kg}$ b.w. daily) on pulmonary tissue of cigarette smoke induced in Balb/c mice by reducing mucin production, citrulline and NO levels, and peroxidative damage [130].

\section{Conclusions}

Aloe vera has been traditionally used to treat skin injuries (burns, cuts, insect bites, and eczemas) and digestive problems because of its anti-inflammatory, antimicrobial, and wound healing properties. Research on this medicinal plant has been aimed at validating traditional uses and deepening the mechanism of action, identifying the compounds responsible for these activities. Likewise, new actions have been investigated for Aloe vera and its active compounds, especially highlighting its promising role as a cytotoxic, antitumoral, anticancer, and antidiabetic agent. In the last 6 years, most pharmacological studies have been in vitro and in vivo works. Among in vitro studies, antimicrobial, anti-inflammatory, cytotoxic, antitumor, anticancer, and skin protection activities are the most studied in number. It should be especially noted that among in vitro studies there are several works that evaluate the protective action of Aloe vera in bone diseases such as osteoporosis. The results on bone protection are promising; however, it is necessary to perform them with experimental animals and humans. Regarding in vivo studies, these are aimed at evaluating cardioprotective effect, cytotoxic, antitumor and anticancer activities, and skin protection activities. Compared to in vitro and in vivo assays, clinical trials are limited and focus on digestive and skin protective effects. In addition, these clinical trials have been conducted just with Aloe vera, but not with its isolated compounds; therefore, it would be of interest to study the clinical effect of relevant metabolites in different human conditions and 
pathologies. Among the major active compounds, research in the last six years focused on aloe-emodin, aloin, aloesin, amodin, and acemannan. Of these, aloe-emodin and aloin have been the most studied ones. Particularly, aloe-emodin has resulted to be a promising agent as an antimicrobial, antidiabetic, cytotoxic, cardiprotective, and bone protective (in in vitro studies) as well as anti-inflammatory and skin protective compound (in in vivo studies). Aloin was effective in inflammatory process and bone diseases (in vitro studies) and in cancer and cardiovascular diseases (in vivo studies). The promising results of basic research encourage a greater number of clinical trials to test the clinical application of Aloe vera and its main compounds, particularly on bone protection, cancer, and diabetes. 
Table 1. In vitro pharmacological studies for Aloe vera.

\begin{tabular}{|c|c|c|c|}
\hline Aloe Vera Composition & Experimental Model & Major Findings & References \\
\hline \multicolumn{4}{|c|}{ Digestive Diseases Protection } \\
\hline Acemannan & Human deciduous pulp cells & $\begin{array}{c}\uparrow \text { Pulp cell proliferation } \\
\uparrow \text { ALP } \\
\uparrow \text { Type I collagen } \\
\uparrow \text { BMP-2, BMP-4, vascular endothelial growth factor and dentin } \\
\text { sialoprotein expression }\end{array}$ & [6] \\
\hline Aloe polysaccharide & HT-29 cells LPS and TNF- $\alpha$ induced & $\begin{array}{c}\uparrow \text { JAK2 and STAT-3 expression } \\
\downarrow \text { JAK2, p-JAK2, STAT-3 and p-STAT3 protein expression } \\
\text { Ulcerative colitis protection }\end{array}$ & [5] \\
\hline Aloe vera extract & Dental pulp stem cells from rabbits & $\uparrow$ Cell viability & [4] \\
\hline \multicolumn{4}{|c|}{ Skin Protection } \\
\hline Aloe polysaccharide & HaCaT cells & $\begin{array}{c}\downarrow \text { TNF- } \alpha \text { levels } \\
\downarrow \text { IL-8 and IL-12 expression levels } \\
\downarrow \text { p65 expression } \\
\uparrow I k B \text {-alpha protein expression } \\
\text { Psoriasis protection }\end{array}$ & [49] \\
\hline Aloe vera & HEKa and NFDH cells & $\begin{array}{l}\uparrow \text { Cell viability } \\
\uparrow \text { Cell proliferation } \\
\uparrow \text { Cell migration } \\
\uparrow \text { Wound healing }\end{array}$ & [31] \\
\hline Aloe vera & HaCaT cells & $\begin{array}{c}\downarrow \text { Photodamage } \\
\text { Membrane integrity maintenance } \\
\uparrow \text { Lysosomal stability }\end{array}$ & {$[32]$} \\
\hline Aloe vera ethanolic extract & c147 cells & $\begin{array}{l}\uparrow \text { Fibroblast migration } \\
\uparrow \text { VEGF-A gene expression } \\
\uparrow \text { Wound healing }\end{array}$ & {$[30]$} \\
\hline Aloe vera gel & Mouse embryonic fibroblast cells & $\begin{array}{c}\uparrow \text { TFG } \beta 1 \text { and bFGF factor expression } \\
\uparrow \text { Wound healing }\end{array}$ & [29] \\
\hline
\end{tabular}


Table 1. Cont.

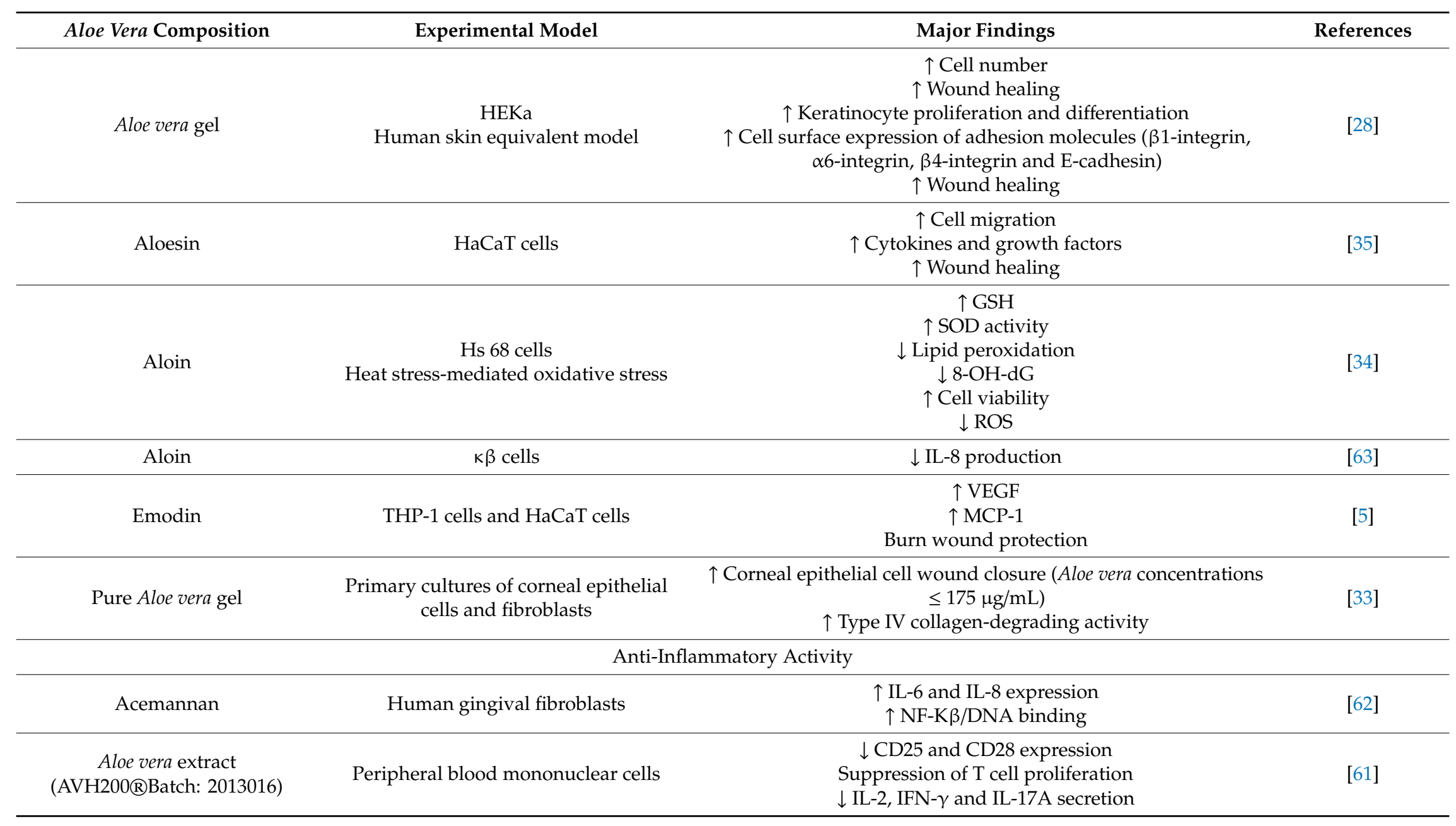


Table 1. Cont

\begin{tabular}{|c|c|c|c|}
\hline Aloe Vera Composition & Experimental Model & Major Findings & References \\
\hline $\begin{array}{l}\text { Aloe-emodin } \\
\text { sulfates/glucuronides, rhein } \\
\text { sulfates/glucuronides, } \\
\text { aloe-emodin and rhein }\end{array}$ & $\begin{array}{l}\text { RAW } 264.7 \text { cells stimulated with LPS and } \\
\text { mouse peritoneal excluded macrophages }\end{array}$ & $\begin{array}{l}\downarrow \text { iNOS expression } \\
\downarrow \text { TNF- } \alpha \text {, IL-12, and NO production } \\
\downarrow \text { MAPKs phosphorylation }\end{array}$ & [64] \\
\hline Aloin & RAW 264.7 cells & $\begin{array}{c}\downarrow \text { iNOS expression } \\
\downarrow \text { IL-1 } \beta, \text { IL-6, tumor necrosis factor alpha and NO } \\
\text { dose-dependently } \\
\downarrow \text { JAK1-STAT1/3 activation } \\
\downarrow \text { STAT1/3 nuclear translocation } \\
\downarrow \text { ROS production }\end{array}$ & [59] \\
\hline Aloin & KB cells & $\begin{array}{l}\downarrow \text { Salivary IL-1 } \beta \text {-induced IL-8 production } \\
\downarrow \text { p38 and ERK pathway }\end{array}$ & {$[63]$} \\
\hline Barbaloin/aloin & RAW 264.7 cells stimulated with LPS & 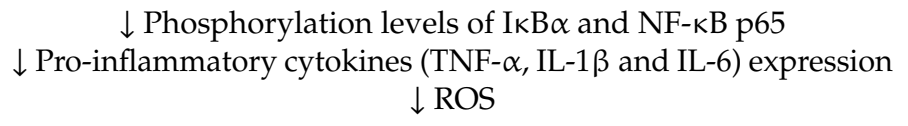 & {$[60]$} \\
\hline \multicolumn{4}{|c|}{ Anticancer Effects } \\
\hline Aloe polysaccharide & BxPC-3 cells & $\begin{array}{c}\uparrow \text { ULK1 mRNA expression } \\
\downarrow \text { BECN1 and BCL-2 mRNA expression }\end{array}$ & [77] \\
\hline Aloe vera crude extract & MCF-7 cells and HeLa cells & $\begin{array}{c}\downarrow \text { Cell viability } \\
\text { Apoptosis induction } \\
\downarrow \text { Cyclin D1, CYP1A1 and CYP1A2 } \\
\uparrow \text { Bax and p21 expression }\end{array}$ & {$[68]$} \\
\hline Aloe-emodin & $\begin{array}{l}\text { Metastatic human melanoma cell lines } \\
\text { Primary stem-like cells }\end{array}$ & $\begin{array}{c}\downarrow \text { Cell proliferation } \\
\uparrow \text { Cell differentiation } \\
\uparrow \text { Transamidating activity of transglutaminase } \\
\uparrow \text { Dabrafenib antiproliferative activity }\end{array}$ & [85] \\
\hline Aloe-emodin & TE1 cancer cells & $\begin{array}{c}\downarrow \text { AKT and ERK phosphorylation } \\
\downarrow \text { Number cells in } S \text { phase }\end{array}$ & {$[76]$} \\
\hline
\end{tabular}


Table 1. Cont.

\begin{tabular}{|c|c|c|c|}
\hline Aloe Vera Composition & Experimental Model & Major Findings & References \\
\hline Aloe-emodin & $\begin{array}{c}\text { MCF-7 cells } \\
\text { Photodynamic therapy }\end{array}$ & $\begin{array}{c}\qquad \text { Adhesion, migration and invasion of cells } \\
\text { cytoskeleton disorganization } \\
\text { Apoptosis: mitochondrial and endoplasmic reticulum death } \\
\text { pathways }\end{array}$ & {$[70]$} \\
\hline Aloe-emodin & $\begin{array}{c}\text { HUVECs cells } \\
\text { Photodynamic therapy }\end{array}$ & $\begin{array}{c}\downarrow \text { Angiogenesis and Cell Metastasis } \\
\text { MAPK Signaling Pathway activation } \\
\downarrow \text { Adhesion, migration and invasion of cells } \\
\text { Apoptosis: mitochondrial death pathways } \\
\text { cytoskeleton disorganization }\end{array}$ & [79] \\
\hline Aloe-emodin & SW620 and HT29 cells & 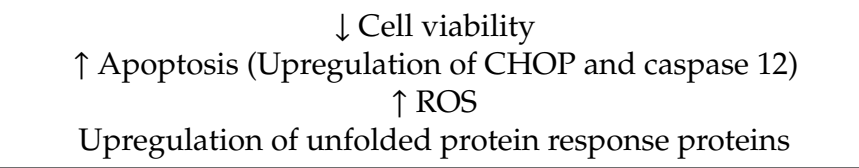 & [79] \\
\hline Aloe-emodin & HeLa cells & $\begin{array}{c}\downarrow \text { Cell proliferation } \\
\text { G2/M and S phase cell cycle arrest } \\
\uparrow \text { Radiosensitivity } \\
\uparrow \text { Cyclin B and } \gamma \text {-H2AX expression } \\
\uparrow \text { ALP activity }\end{array}$ & [69] \\
\hline Aloe-emodin & MG-63 cells & $\begin{array}{c}\uparrow \text { ROS production } \\
\downarrow \text { Mitochondrial membrane potential } \\
\uparrow \text { Caspase-3, caspase-9, caspase-12 expression } \\
\uparrow \text { Cytochrome c release }\end{array}$ & [82] \\
\hline Aloe-emodin & HeLa cells & $\begin{array}{l}\uparrow \text { Mitotic death } \\
\downarrow \text { Mitotic index } \\
\downarrow \text { G2/M phase }\end{array}$ & [72] \\
\hline Aloe-emodin & $\begin{array}{l}\text { Breast cancer cells (MCF-7, } \\
\text { MDA-MB-231, MDA-MB-468, BT-474, } \\
\text { HCC-1954) }\end{array}$ & $\uparrow$ Tamoxifen cytotoxicity & {$[71]$} \\
\hline Aloe-emodin & MG-63 cells & $\begin{array}{l}\downarrow \text { Cell viability } \\
\uparrow \text { Autophagy } \\
\uparrow \text { Apoptosis } \\
\uparrow \text { ROS }\end{array}$ & [83] \\
\hline
\end{tabular}


Table 1. Cont.

\begin{tabular}{|c|c|c|c|}
\hline Aloe Vera Composition & Experimental Model & Major Findings & References \\
\hline Aloesin & SKOV3 cells & $\begin{array}{c}\downarrow \text { Cell viability } \\
\downarrow \text { Cell clonality } \\
\downarrow \text { Cell cycle at S-phase } \\
\uparrow \text { Apoptosis } \\
\downarrow \text { Migration and invasion cancer }\end{array}$ & {$[74]$} \\
\hline Emodin & KB cells & $\begin{array}{c}\downarrow \text { Cell proliferation } \\
\uparrow \text { Caspase-3 upregulation } \\
\uparrow \text { Bax protein levels } \\
\downarrow \text { Bcl-2 protein levels }\end{array}$ & [75] \\
\hline \multicolumn{4}{|c|}{ Antidiabetic Effect } \\
\hline Aloe vera polysaccharides & $\begin{array}{l}\text { Hamster pancreatic } \beta \text {-cell line HIT-T15 } \\
\text { in response to free fatty acids }\end{array}$ & $\begin{array}{c}\downarrow \text { Number of apoptotic } \beta \text {-cell death } \\
\text { Relief of endoplasmic reticulum stress signaling }\end{array}$ & [91] \\
\hline Aloe-emodin & $\begin{array}{l}\text { RIN-5F cells } \\
\text { High glucose induced toxicity }\end{array}$ & $\begin{array}{c}\uparrow \text { Cell viability } \\
\downarrow \text { ROS generation } \\
\downarrow \text { Pro-inflammatory cytokines levels (IFN- } \gamma, \text { IL-1 } \beta \text { ) } \\
\uparrow \text { Anti-inflammatory cytokine levels (IL-6 and IL-10) } \\
\downarrow \text { DNA fragmentation } \\
\downarrow \text { Bax, caspase 3, Fadd, and Fas expression } \\
\uparrow \text { Bcl-2 expression }\end{array}$ & [92] \\
\hline \multicolumn{4}{|c|}{ Antioxidant Properties } \\
\hline $\begin{array}{c}\text { Aloe vera crude methanolic } \\
\text { extracts }\end{array}$ & $\begin{array}{c}\text { In vitro antioxidant methods: DPPH, } \\
\text { metal chelating, hydrogen peroxide } \\
\text { scavenging, reducing power and } \\
\beta \text {-carotene-linoleic }\end{array}$ & Antioxidant activity & [95] \\
\hline Aloe vera ethanol extracts & $\begin{array}{c}\text { Cell models (HeLa, HMEC, HaCat, and } \\
\text { HOS) hydrogen peroxide and } \\
\text { 4-hydroxynonenal induced }\end{array}$ & $\begin{array}{c}\downarrow \text { ROS production } \\
\downarrow \text { HNE protein adducts } \\
\text { HMEC cells were the most sensitive }\end{array}$ & [96] \\
\hline $\begin{array}{c}\text { Anthraquinone derivatives } \\
\text { Phenolic derivatives } \\
\text { Chromones } \\
\text { Pyrones }\end{array}$ & $\begin{array}{l}\text { Peroxyl radical scavenging } \\
\text { Reducing capacity }\end{array}$ & Antioxidant activity & [97] \\
\hline
\end{tabular}


Table 1. Cont

\begin{tabular}{|c|c|c|c|}
\hline Aloe Vera Composition & Experimental Model & Major Findings & References \\
\hline \multicolumn{4}{|c|}{ Bone Protection } \\
\hline Aloe-emodin & ATDC5 cells & $\begin{array}{c}\uparrow \text { Accumulation cartilage nodules } \\
\uparrow \text { Matrix proteoglycans synthesis } \\
\uparrow \text { ALP activity } \\
\uparrow \text { Chondrogenic marker genes } \\
\uparrow \text { ERKs } \\
\uparrow \text { BMP-2 protein expression }\end{array}$ & [99] \\
\hline Aloin & RAW264.7 cells & $\begin{array}{c}\downarrow \text { TRAP content } \\
\uparrow \text { F4/80 content } \\
\downarrow \text { Cathepsin K } \\
\downarrow \text { RANKL-induced NF- } \kappa \text { B pathway } \\
\downarrow \text { DNA binding activity of NF- } \kappa \mathrm{B} \\
\text { Osteoporosis protection }\end{array}$ & [100] \\
\hline Aloe emodin & Model heme protein (hemoglobin) & $\downarrow$ Hemoglobin aggregation (máximum effect at $100 \mu \mathrm{M}$ ) & [106] \\
\hline \multicolumn{4}{|c|}{ Antimicrobial and Prebiotic Activity } \\
\hline Acemannan and fructans & $\begin{array}{c}\text { Lactobacillus and Bifidobacterium species } \\
\text { Human fecal bacteria }\end{array}$ & $\begin{array}{c}\uparrow \text { Bacterial growth (fructans) } \\
\uparrow \text { Bifidobacterium spp population } \\
\uparrow \text { Acetate concentrations }\end{array}$ & [120] \\
\hline Aloe polysaccharides & H1N1 subtype Influenza A virus & $\begin{array}{c}\downarrow \text { H1N1 subtype influenza virus replication } \\
\downarrow \text { Viral adsorption period }\end{array}$ & [117] \\
\hline Aloe vera aqueous extract & Methicillin resistant Staphylococcus aureus & $\begin{array}{c}\downarrow \text { Growth } \\
\downarrow \text { Biofilm formation } \\
\end{array}$ & [109] \\
\hline Aloe vera aqueous extracts & Drug resistant Mycobacterium tuberculosis & $\begin{array}{l}\text { Inhibition zone: } 60 \mathrm{~mm} \text { (disk diffusion method) } \\
\downarrow \text { Cell growth (up to } 1 \mathrm{mg} / \mathrm{mL} \text { concentration) (pour plate method) }\end{array}$ & [115] \\
\hline Aloe vera crude aqueous extracts & Plasmodium falciparum & Antiplasmodial activity & [95] \\
\hline
\end{tabular}


Table 1. Cont

\begin{tabular}{|c|c|c|c|}
\hline Aloe Vera Composition & Experimental Model & Major Findings & References \\
\hline Aloe vera extracts & $\begin{array}{l}\text { Multidrug-resistant } P \text { seudomonas } \\
\text { aeruginosa }\end{array}$ & Similar $\mathrm{MIC}_{50}$ and $\mathrm{MIC}_{90}$ & [112] \\
\hline Aloe vera gel & $\begin{array}{l}\text { Actinobacillus actinomycetemcomitans } \\
\text { Clostridium bacilli, Streptcoccus mutans } \\
\text { and Staphlococcus aureus }\end{array}$ & Antibacterial activity against oral pathogens & [110] \\
\hline Aloe vera gel & Virus herpes simplex 1 & $\downarrow$ HSV-1 growth & [116] \\
\hline Aloe vera hydroalcoholic extract & Enterococcus facecalis & Antibacterial activity against Enterococcus faecalis & [114] \\
\hline Aloe vera inner gel & $\begin{array}{l}\text { Gram negative bacteria, Gram positive } \\
\text { bacteria and Candida albicans }\end{array}$ & $\begin{array}{c}\text { Antimicrobial and antibiofilm activities against Gram negative } \\
\text { bacteria (Helicobacter pylori, Escherichia coli and Pseudomonas } \\
\text { aeruginosa) and Candida albicans }\end{array}$ & [113] \\
\hline Aloe vera mucilage & $\begin{array}{l}\text { Intestinal microbiota from healthy } \\
\text { donors }\end{array}$ & 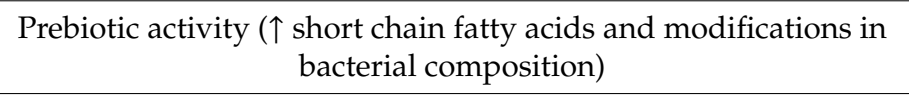 & [119] \\
\hline Aloe-emodin & Staphylococcus aureus & $\begin{array}{c}\downarrow \text { Biofilm development (initial adhesion and proliferation stages) } \\
\text { and extracellular protein production }\end{array}$ & [111] \\
\hline \multicolumn{4}{|c|}{ Other Effects } \\
\hline Aloe-emodin & $\begin{array}{l}\text { MH7A human RA synovial } \\
\text { fibroblast-like cells }\end{array}$ & $\begin{array}{l}\qquad \text { Viable cells number } \\
\uparrow \text { Apoptosis (G2/M phase arrest) } \\
\text { Rheumatoid arthritis protection }\end{array}$ & [127] \\
\hline Aloe-emodin & ARPE-19 cells & $\begin{array}{c}\downarrow \text { VEGF secretion } \\
\downarrow \text { VEGFA and PHD-2 mRNA expression } \\
\downarrow \text { VEGFA, HIF- } 1 \alpha \text { and PHD-2 protein expression }\end{array}$ & [131] \\
\hline
\end{tabular}

Table 2. In vivo pharmacological studies for Aloe vera.

\begin{tabular}{ccc}
\hline Aloe Vera Composition & Experimental Model & Major Findings \\
\hline Acemannan & Digestive Diseases Protection & Mineralized Bridge Formation \\
\hline Aloe polysaccharide & $\begin{array}{c}\text { B,4,6-three nitrobenzene sulfonic acid } \\
\text { colitis induced } \\
\text { Rats }\end{array}$ & $\begin{array}{c}\uparrow \text { JAK2, p-JAK2, STAT-3 and p-STAT3 protein expression } \\
\downarrow \text { Ulcerative colitis }\end{array}$ \\
\hline
\end{tabular}


Table 2. Cont

\begin{tabular}{|c|c|c|c|}
\hline Aloe Vera Composition & Experimental Model & Major Findings & References \\
\hline Aloe vera gel & $\begin{array}{l}\text { Balb/c mouse model of alcohol-induced } \\
\text { acute gastritis }\end{array}$ & $\uparrow$ Matrix metalloproteinase-9 inhibitory activity & [24] \\
\hline Aloe vera & $\begin{array}{l}\text { Male Wistar rats } \\
\text { Irradiated model }\end{array}$ & $\uparrow$ Salivary flow rate & [7] \\
\hline \multicolumn{4}{|c|}{ Skin Protection } \\
\hline Aloe emodin & BALB/c mice burn wound-induced & $\uparrow$ Wound healing activity ( $\uparrow$ re-epithelialization and angiogenesis) & [6] \\
\hline Aloe sterols & $\begin{array}{l}\text { Female HR-1 hairless mice } \\
\text { Ultraviolet B-induced skin photoaging }\end{array}$ & $\begin{array}{c}\downarrow \text { Skin dryness, epidermal thickness and wrinkle formation } \\
\downarrow \text { Dermal collagen fibers degeneration } \\
\downarrow \text { Cutaneous apoptosis cells } \\
\downarrow \text { Pro-inflammatory cytokines } \\
\downarrow \text { Matrix metalloproteinases }\end{array}$ & [43] \\
\hline Aloe vera & $\begin{array}{c}\text { Adult male Wistar rats with incision on } \\
\text { neck }\end{array}$ & $\begin{array}{c}\uparrow \text { Fibroblasts } \\
\uparrow \text { TGF- } \beta \text { gene expression }\end{array}$ & [38] \\
\hline Aloe vera & $\begin{array}{l}\text { Adult female Sprague Dawley rats with } \\
\text { a skin wound infected with } \\
\text { methicillin-resistant Staphylococcus aureus }\end{array}$ & $\begin{array}{c}\downarrow \text { Inflammatory cell infiltration } \\
\uparrow \text { Wound closure and skin tensile strength \% } \\
\uparrow \text { Collagen deposition } \\
\uparrow \text { Skin tensile strength }\end{array}$ & [132] \\
\hline Aloe vera aqueous gel extract & X-ray irradiated Male balb/c mice & $\begin{array}{c}\uparrow \text { Hepatic and renal function parameters } \\
\downarrow \text { ROS } \\
\downarrow \text { Lipid peroxidation } \\
\uparrow \text { GSH } \\
\uparrow \text { GR, GPx, CAT, SOD, GST } \\
\uparrow \text { Sperm count/motility and testosterone levels }\end{array}$ & [45] \\
\hline Aloe vera cream & Male Sprague-Dawley rats & $\begin{array}{c}\downarrow \text { Wound percentage } \\
\downarrow \text { Leucocytes infiltration } \\
\downarrow \text { Angiogenesis } \\
\downarrow \text { CD8 }{ }^{+} \text {lymphocytes expression } \\
\uparrow \text { Epidermal thickness } \\
\uparrow \mathrm{CD} 4^{+} \text {lymphocytes expression }\end{array}$ & [39] \\
\hline Aloe vera extract gel & $\begin{array}{l}\text { Wistar rats with a wound made by } \\
\text { incision }\end{array}$ & $\uparrow$ Organization of skin and collagen & [36] \\
\hline
\end{tabular}


Table 2. Cont

\begin{tabular}{|c|c|c|c|}
\hline Aloe Vera Composition & Experimental Model & Major Findings & References \\
\hline Aloe vera gel & $\begin{array}{l}\text { Male Wistar rats } \\
\text { Alloxan-induced diabetes with wounds }\end{array}$ & $\begin{array}{c}\downarrow \text { Necrotic tissue and inflammation } \\
\qquad \text { Wound areas } \\
\text { Better reepithelialization }\end{array}$ & [40] \\
\hline Aloe vera gel & Male Wistar rats & $\begin{array}{c}\uparrow \text { Wound contraction and epithelialization } \\
\downarrow \text { Scar tissue size } \\
\uparrow \text { Alignment and organization of regenerated scar tissue }\end{array}$ & [37] \\
\hline Aloe vera gel aqueous extract & X-ray irradiated Male balb/c mice & $\begin{array}{l}\uparrow \text { Hepatic and renal function parameters } \\
\downarrow \text { ROS, } \downarrow \text { Lipid peroxidation } \\
\downarrow \text { Lactate dehydrogenase }\end{array}$ & [45] \\
\hline Aloe vera gel powder & $\begin{array}{l}\text { Ovariectomy HR-1 hairless mice } \\
\text { UV-irradiation model }\end{array}$ & $\begin{array}{c}\downarrow \text { Matrix metalloproteinases (MMPs) expression } \\
\uparrow \text { Epidermal growth factor } \\
\uparrow \text { Hyaluronan synthase }\end{array}$ & [41] \\
\hline Aloe vera gel powder & $\begin{array}{l}\text { HR-1 hairless mice } \\
\text { UVB-induced model }\end{array}$ & $\begin{array}{c}\uparrow \text { Skin elasticity } \\
\downarrow \text { Matrix metalloproteinase } 2,9 \text { and } 13 \\
\uparrow \text { Hyaluronic content } \\
\uparrow \text { HA synthase } 2\end{array}$ & {$[42]$} \\
\hline Aloe vera hydroalcoholic extract & Wistar rats with traumatic ulcers & No acceleration of oral wound & [133] \\
\hline Aloesin & SKH-1 hairless mice & $\begin{array}{c}\uparrow \text { Angiogenesis } \\
\uparrow \text { Collagen deposition and granulation tissue formation }\end{array}$ & {$[35]$} \\
\hline \multicolumn{4}{|c|}{ Anti-Inflammatory Activity } \\
\hline Aloe vera & $\begin{array}{l}\text { Male ICR strain mice } \\
\text { Acetaminophen-induced hepatitis }\end{array}$ & $\begin{array}{c}\downarrow \text { Hepatic MDA } \\
\downarrow \text { IL-12 and IL-18 } \\
\downarrow \text { ALT transaminase } \\
\quad \downarrow \text { Hepatitis }\end{array}$ & {$[65]$} \\
\hline $\begin{array}{l}\text { Aloe-emodin } \\
\text { sulfates/glucuronides, rhein } \\
\text { sulfates/glucuronides, } \\
\text { aloe-emodin and rhein }\end{array}$ & LPS-induced septic mice & $\downarrow$ NO level & {$[61]$} \\
\hline Barbaloin & $\begin{array}{l}\text { BALB/c mice LPS-induced acute lung } \\
\text { injury }\end{array}$ & Histological analysis revealed certain protective effect & {$[60]$} \\
\hline
\end{tabular}


Table 2. Cont

\begin{tabular}{|c|c|c|c|}
\hline Aloe Vera Composition & Experimental Model & Major Findings & References \\
\hline \multicolumn{4}{|c|}{ Anticancer Effects } \\
\hline Aloe vera aqueous extract & Male Swiss albino mice & $\begin{array}{l}\text { Mutagenic activity } \\
\text { Cytotoxic effect } \\
\text { Wound healing (antioxidant properties) }\end{array}$ & [47] \\
\hline Aloe vera extract & Mice with breast cancer by implantind & $\begin{array}{l}\downarrow \text { COX-2 level } \\
\downarrow \text { VEGF levels }\end{array}$ & [73] \\
\hline Aloe vera powder and extract & $\begin{array}{l}\text { C57BL/6J mice high-fat diet induced and } \\
\text { azoxymethane induced aberrant crypt } \\
\text { foci colorectal cancer }\end{array}$ & $\begin{array}{c}\uparrow \text { Hepatic phase II enzyme glutathione S-transferase mRNA } \\
\text { levels } \\
\downarrow \text { Cell proliferation in the colonic mucosa } \\
\downarrow \text { Number of aberrant crypt foci }\end{array}$ & [80] \\
\hline Aloe vera gel & $\begin{array}{l}\text { BALB/c female mice with induced } \\
\text { colitis-associated colon carcinogenesis }\end{array}$ & $\begin{array}{c}\downarrow \text { Multiplicity of colonic adenomas and adenocarcinomas } \\
\downarrow \text { Adenoma and adenocarcinoma development } \\
\downarrow \text { Activation of nuclear factor kappa B } \\
\downarrow \text { Inducible nitric oxide synthase and cyclooxygenase-2 } \\
\quad \text { expression } \\
\downarrow \text { Cell cycle progression-inducing cellular factors }\end{array}$ & [125] \\
\hline Aloin & Male Swiss albino rats & $\begin{array}{c}\uparrow \text { Erythropoiesis impairment } \\
\uparrow \text { Serum iron level } \\
\text { No changes on serum lipid profile } \\
\text { No changes on serum elements and kidney function parameters }\end{array}$ & [105] \\
\hline Emodin & SPF BALB/c-nu nude mice & $\begin{array}{l}\uparrow \text { Survival time of tumor } \\
\downarrow \text { Effect on transplantation tumors } \\
\qquad \text { Oral cancer }\end{array}$ & [75] \\
\hline \multicolumn{4}{|c|}{ Antidiabetic Effect } \\
\hline Aloe vera extract & $\begin{array}{l}\text { Streptozotocin-induced diabetic Wistar } \\
\text { rats }\end{array}$ & $\begin{array}{c}\downarrow \text { Blood glucose levels } \\
\uparrow \text { Insulin levels } \\
\uparrow \text { Number, diameter, volume and area of pancreatic islets }\end{array}$ & [88] \\
\hline
\end{tabular}


Table 2. Cont.

\begin{tabular}{|c|c|c|c|}
\hline Aloe Vera Composition & Experimental Model & Major Findings & References \\
\hline Aloe vera extract & $\begin{array}{l}\text { Streptozotocin-induced nephropathy } \\
\text { diabetic Wistar rats }\end{array}$ & $\begin{array}{c}\downarrow \text { Development of nephropathy } \\
\downarrow \text { Lipid alteration } \\
\downarrow \text { Renal oxidative stress } \\
\text { Direct renoprotective action }\end{array}$ & [89] \\
\hline Aloe vera gel & $\begin{array}{c}\text { Streptozotocin-induced diabetic male } \\
\text { Wistar rats }\end{array}$ & $\begin{array}{c}\downarrow \text { Anxiety/depression-like behaviors } \\
\uparrow \text { Exploratory and locomotor activities } \\
\uparrow \text { Memory performance } \\
\downarrow \text { Stress related behaviors } \\
\downarrow \text { Oxidative stress } \\
\uparrow \text { Neuronal loss in hippocampus }\end{array}$ & [134] \\
\hline Aloe vera lyophilized extract & $\begin{array}{l}\text { Wistar rats with corneal alkali-burn } \\
\text { injury } \\
\text { Normal rats and diabetic rats } \\
\text { streptozotocin-induced }\end{array}$ & $\begin{array}{c}\uparrow \text { Wound healing (especially in diabetic rats) } \\
\downarrow \begin{array}{l}\downarrow \text { Edema } \\
\text { Complete and higher corneal re-epithelialization }\end{array}\end{array}$ & {$[90]$} \\
\hline Aloe vera polysaccharides & $\begin{array}{c}\text { C57BL/KsJ-db/db male mice fed with } \\
\text { high fat diet }\end{array}$ & $\downarrow$ Fasting blood glucose levels & [91] \\
\hline \multicolumn{4}{|c|}{ Cardioprotective Effect } \\
\hline Aloe vera & $\begin{array}{c}\text { Wistar albino rats } \\
\text { Spinal cord ischemia reperfusion injury } \\
\text { model }\end{array}$ & $\begin{array}{c}\downarrow \text { MDA levels } \\
\downarrow \text { NF- } \kappa \beta \text { and nNOS expressions } \\
\downarrow \text { Hemorrhage } \\
\downarrow \text { Edema } \\
\downarrow \text { Inflammatory cell migration } \\
\downarrow \text { Neurons }\end{array}$ & [102] \\
\hline Aloe vera extract & $\begin{array}{l}\text { Wistar Albino rats with } \\
\text { ischemia-reperfusion injury of sciatic } \\
\text { nerve }\end{array}$ & $\begin{array}{c}\downarrow \text { Ischemic fiber degeneration } \\
\downarrow \text { MDA } \\
\uparrow \text { NRF1 level } \\
\uparrow \text { SOD activity }\end{array}$ & [108] \\
\hline Aloe vera gel & $\begin{array}{l}\text { Male Wistar albino rats } \\
\text { Ischemia reperfusion injury model }\end{array}$ & $\begin{array}{c}\uparrow \text { SOD, CAT and GPx } \\
\downarrow \text { MDA levels }\end{array}$ & [103] \\
\hline
\end{tabular}


Table 2. Cont.

\begin{tabular}{|c|c|c|c|}
\hline Aloe Vera Composition & Experimental Model & Major Findings & References \\
\hline Aloe vera gel & $\begin{array}{l}\text { Male Wistar Albino rats } \\
\text { Sciatic nerve ischemia model }\end{array}$ & $\begin{array}{c}\downarrow \text { Ischemic fiber degeneration } \\
\downarrow \text { MDA content } \\
\uparrow \text { NRF1 level and SOD activity } \\
\text { Neuroprotection }\end{array}$ & [108] \\
\hline Aloe-emodin & Male Wistar rats & $\begin{array}{c}\downarrow \text { Total cholesterol } \\
\downarrow \text { Low-density lipoprotein-cholesterol } \\
\downarrow \text { Hyperlipidemia }\end{array}$ & [107] \\
\hline Aloe-emodin & $\begin{array}{l}\text { Sprague Dawley rats } \\
\text { Hypoxia conditions }\end{array}$ & $\downarrow$ Hypoxia-induced retinal neovascularization & [131] \\
\hline Aloin & Swiss albino rats & $\begin{array}{c}\downarrow \text { Triacylglycerols } \\
\downarrow \text { Total cholesterol } \\
\downarrow \text { Cholesteryl esters } \\
\downarrow \text { Low density lipoprotein-cholesterol } \\
\downarrow \text { Very low density lipoprotein-cholesterol } \\
\downarrow \text { Urea } \\
\downarrow \text { Creatinine } \\
\downarrow \text { Blood hemoglobin concentration } \\
\uparrow \text { Serum iron level }\end{array}$ & [105] \\
\hline Barbaloin/aloin & $\begin{array}{c}\text { Sprague-Dawley rats } \\
\text { Myocardial ischemia/reperfusion injury } \\
\text { model }\end{array}$ & $\begin{array}{l}\downarrow \mathrm{I} / \mathrm{R} \text { induced myocardial oxidative stress and inflammatory } \\
\text { response } \\
\uparrow \text { AMPK signaling }\end{array}$ & [104] \\
\hline \multicolumn{4}{|c|}{ Antimicrobial and Prebiotic Activity } \\
\hline Aloe polysaccharides & $\begin{array}{l}\text { PR8(H1N1) virus infection SPF BALB/c } \\
\text { mice }\end{array}$ & $\begin{array}{l}\text { Clinical symptoms improvement } \\
\text { Lung damage improvement }\end{array}$ & [117] \\
\hline \multicolumn{4}{|c|}{ Other Effects } \\
\hline Aloe vera aqueous extract & $\begin{array}{l}\text { Female Wistar albino rats } \\
\text { Morphine dependent model }\end{array}$ & $\downarrow$ Agitation, disparity and floppy eyelids & [129] \\
\hline Aloe vera aqueous extract & $\begin{array}{l}\text { Wistar rats drug-induced sleeping and } \\
\text { anesthesia and analgesia }\end{array}$ & 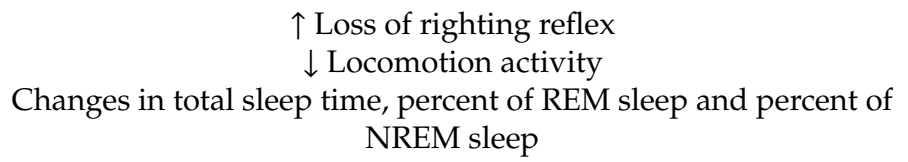 & [135] \\
\hline
\end{tabular}


Table 2. Cont.

\begin{tabular}{|c|c|c|c|}
\hline Aloe Vera Composition & Experimental Model & Major Findings & References \\
\hline Aloe vera ethanol extract & Wistar rats & $\begin{array}{c}\uparrow \text { Mounting frequency } \\
\uparrow \text { Intromission frequency } \\
\downarrow \text { Mount and intromission latencies } \\
\uparrow \text { Ejaculatory latency } \\
\uparrow \text { Testosterone and cholesterol concentrations }\end{array}$ & [122] \\
\hline Aloe vera ethanol extract & Rats & $\begin{array}{l}\downarrow \text { TNF- } \alpha \text { levels } \\
\downarrow \text { NK cells } \\
\downarrow \text { Th17 cells percentage } \\
\text { Hepatoprotective }\end{array}$ & [136] \\
\hline Aloe vera gel & $\begin{array}{l}\text { C57BL/6 female mice } \\
\text { C3H/HeJ mice }\end{array}$ & $\begin{array}{c}\uparrow \text { Lymphocyte and erythrocytes number } \\
\text { Lymphopenia and erythropenia restoration } \\
\text { IgA secretion restoration }\end{array}$ & [125] \\
\hline Aloe vera gel extract & $\begin{array}{l}\text { Wistar rats Bisphenol A Induced } \\
\text { Testicular Toxicity }\end{array}$ & $\begin{array}{c}\uparrow \text { Body and testis weights } \\
\uparrow \text { Seminiferous tubule diameter and height of seminiferous } \\
\text { epithelium } \\
\uparrow \text { Quantity of spermatocyte and spermatids } \\
\downarrow \text { MDA } \\
\uparrow \text { GSH }\end{array}$ & [123] \\
\hline Aloe vera gel extract & $\begin{array}{l}\text { Balb/c mice pulmonary tissue of cigarette } \\
\text { smoke induced }\end{array}$ & 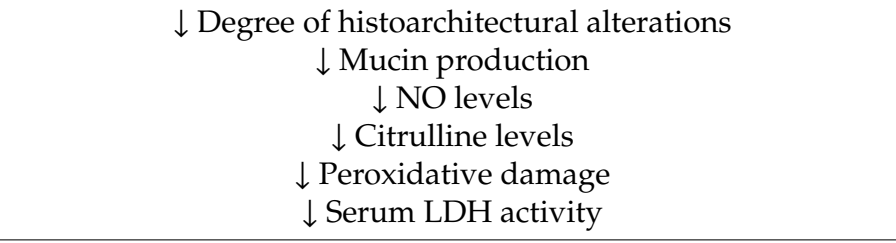 & [130] \\
\hline $\begin{array}{l}\text { Aloe vera lyophilized extract } \\
\text { ointment }\end{array}$ & $\begin{array}{l}\text { Wistar rats with partial transection of } \\
\text { the calcaneal tendon }\end{array}$ & $\begin{array}{c}\uparrow \text { Non-collagenous proteins } \\
\uparrow \text { Content and arrangement of glycosaminoglycans } \\
\downarrow \text { Tendon lesions }\end{array}$ & [128] \\
\hline Aloe vera ethanol & Albino rabbits & $\begin{array}{l}\text { Normalized levels of white blood cells, red blood cells, platelet } \\
\text { count, packed cell volume, mean cell volume and haemoglobin } \\
\text { values } \\
\downarrow \text { MDA } \\
\uparrow \text { CAT }\end{array}$ & [126] \\
\hline
\end{tabular}


Table 2. Cont

\begin{tabular}{|c|c|c|c|}
\hline Aloe Vera Composition & Experimental Model & Major Findings & References \\
\hline Aloe vera gel ethanol extract & Wistar rats & $\begin{array}{c}\downarrow \text { Testes weight } \\
\downarrow \text { Serum testosterone } \\
\downarrow \text { Sperm count } \\
\downarrow \text { Fertility } \\
\uparrow \text { Serum NO } \\
\text { Negative effects on spermatogenesis and sperm quality }\end{array}$ & [121] \\
\hline Aloe vera processed gel & $\begin{array}{l}\text { BALB/c mice on ovalbumin -induced } \\
\text { food allergy }\end{array}$ & $\begin{array}{c}\downarrow \text { Serum concentrations of type } 2 \text { helper T cell (Th2) cytokines } \\
\text { (Interleukin-(IL)-4, IL-5, and IL-13) } \\
\downarrow \text { Histamine } \\
\downarrow \text { Mast cell protease-1 } \\
\downarrow \text { Immunoglobulin IgE } \\
\uparrow \text { IL-10 production } \\
\uparrow \text { Population of type } 1 \text { regulatory T (Tr1) cells } \\
\downarrow \text { Allergy }\end{array}$ & [124] \\
\hline Aloin & F344/N Rats & $\begin{array}{c}\uparrow \text { Incidences and severities of mucosal and goblet cell hyperplasia } \\
\uparrow \text { Shifts in gut microbiota structure }\end{array}$ & [137] \\
\hline
\end{tabular}

Table 3. Clinical trials with Aloe vera.

\begin{tabular}{|c|c|c|c|c|}
\hline Reference & Study Design & $\begin{array}{l}\text { Number of } \\
\text { Patients }\end{array}$ & Intervention & Results \\
\hline \multicolumn{5}{|c|}{ Digestive Diseases Protection } \\
\hline $\begin{array}{l}\text { Anuradha et al. (2017) } \\
\text { [21] } \\
\text { India }\end{array}$ & - & 74 & $\begin{array}{l}\text { Group 1: Aloe vera juice ( } 30 \mathrm{~mL} / \mathrm{twice} \text { daily) } \\
\text { and Aloe vera gel ( } 5 \mathrm{mg} / 3 \text { times daily) for } 3 \\
\text { months } \\
\text { Group 2: intralesional injection of } \\
\text { hydrocortisone }(25 \mathrm{mg} / \mathrm{mL}) \text { and } \\
\text { hyaluronidase ( } 1500 \mathrm{IU}) \text { weekly for } 6 \text { weeks } \\
\text { with antioxidant supplements for } 3 \text { months }\end{array}$ & $\begin{array}{c}\text { Oral submucous fibrosis: } \\
\downarrow \text { Burning sensation } \\
\uparrow \text { Mouth opening, cheek flexibility, and } \\
\text { tongue protrusion }\end{array}$ \\
\hline $\begin{array}{c}\text { Ashouri Moghaddam } \\
\text { et al. (2017) } \\
\text { [12] } \\
\text { Iran }\end{array}$ & Single-blind clinical trial & 20 & $\begin{array}{c}\text { Group 1: Aloe vera gel } \\
\text { Group 2: Placebo (distilled water) }\end{array}$ & $\begin{array}{c}\text { Chronic periodontitis: } \\
\downarrow \text { Gingival index } \\
\downarrow \text { Probing depth }\end{array}$ \\
\hline
\end{tabular}


Table 3. Cont.

\begin{tabular}{|c|c|c|c|c|}
\hline Reference & Study Design & $\begin{array}{l}\text { Number of } \\
\text { Patients }\end{array}$ & Intervention & Results \\
\hline $\begin{array}{l}\text { Fallahi et al. (2016) } \\
\text { [15] } \\
\text { Iran }\end{array}$ & Randomized double blind & 20 & $\begin{array}{l}\text { Group 1: Aloe vera } \\
\text { Group 2: Placebo }\end{array}$ & $\begin{array}{c}\downarrow \text { Swelling } \\
\downarrow \text { Postoperative pain }\end{array}$ \\
\hline $\begin{array}{l}\text { Gupta et al. (2014) } \\
\text { [8] } \\
\text { India }\end{array}$ & $\begin{array}{l}\text { Double blind randomized } \\
\text { control trial }\end{array}$ & 300 & $\begin{array}{c}\text { Group 1: Aloe vera mouthwash group } \\
\text { Group 2: chlorhexidene group } \\
\text { Group 3: Placebo }\end{array}$ & $\downarrow$ Plaque index and gingival index \\
\hline $\begin{array}{l}\text { Ipshita et al. (2018) } \\
\text { [13] } \\
\text { India }\end{array}$ & - & 90 & $\begin{array}{l}\text { Group 1: Placebo } \\
\text { Group 2: } 1 \% \text { alendronate gel } \\
\text { Group 3: Aloe vera gel }\end{array}$ & $\begin{array}{l}\text { Chronic periodontitis: } \\
\uparrow \text { defect depth reduction }\end{array}$ \\
\hline $\begin{array}{c}\text { Kalra et al. (2017) } \\
\text { [16] } \\
\text { India }\end{array}$ & - & 48 & $\begin{array}{l}\text { Group 1: Aloe vera gel } \\
\text { Group 2: mineral trioxide aggregate }\end{array}$ & $\begin{array}{c}\text { Pulpotomy: Success rates was higher in } \\
\text { mineral trioxide aggregate than in Aloe } \\
\text { vera gel }\end{array}$ \\
\hline $\begin{array}{l}\text { Kurian et al. (2018) } \\
\text { [14] } \\
\text { India }\end{array}$ & $\begin{array}{l}\text { Randomized, single-center, } \\
\text { longitudinal, triple-blinded, } \\
\text { parallel arm y }\end{array}$ & 90 & $\begin{array}{l}\text { Group 1: Placebo } \\
\text { Group 2: 1\% metformin gel } \\
\text { Group 3: Aloe vera gel } \\
\text { 6-12 months }\end{array}$ & $\begin{array}{c}\text { Chronic periodontitis: } \\
\downarrow \text { Pocket probing depth } \\
\downarrow \text { Clinical attachment level } \\
\uparrow \text { Bone fill and regeneration }\end{array}$ \\
\hline $\begin{array}{l}\text { Mansouri et al. (2016) } \\
\text { [20] } \\
\text { Iran }\end{array}$ & $\begin{array}{c}\text { Randomized controlled clinical } \\
\text { trial }\end{array}$ & 64 & $\begin{array}{l}\text { Group 1: Aloe vera solution ( } 5 \mathrm{~mL} / \mathrm{two} \\
\text { minutes wash, three times daily) } \\
\text { Group 2: ordinary mouthwashes. } 14 \text { days }\end{array}$ & $\begin{array}{c}\text { Stomatitis: } \downarrow \text { Chemotherapy-induced } \\
\text { Stomatitis in patients with lymphoma } \\
\text { and leukemia }\end{array}$ \\
\hline $\begin{array}{l}\text { Nimma et al. (2017) } \\
{[17]} \\
\text { India }\end{array}$ & $\begin{array}{l}\text { Cross-sectional randomized } \\
\text { interventional study }\end{array}$ & 40 & $\begin{array}{c}\text { Group 1: analgesics (7 days) and socket } \\
\text { healing } \\
\text { Group 2: Aloe vera gel (7 days) and socket } \\
\text { healing }\end{array}$ & $\begin{array}{l}\text { Ulcers: } \\
\downarrow \text { Pain } \\
\uparrow \text { Healing }\end{array}$ \\
\hline $\begin{array}{l}\text { Panahi et al. (2015) } \\
\text { [23] } \\
\text { Iran }\end{array}$ & $\begin{array}{l}\text { Pilot, randomized controlled, } \\
\text { open-label, trial }\end{array}$ & 79 & $\begin{array}{c}\text { Group 1: Aloe vera syrup }(10 \mathrm{~mL} / \text { day }) \\
\text { Group 2: omeprazole capsule }(20 \mathrm{~g} / \text { day }) \\
\text { Group 3: Ranitidine tablet }(150 \mathrm{mg} \text { twice } \\
\text { daily). } 4 \text { weeks }\end{array}$ & $\begin{array}{l}\downarrow \text { Frequency symptoms gastroesophageal } \\
\text { reflux disease }\end{array}$ \\
\hline $\begin{array}{c}\text { Prabhakar et al. (2015) } \\
\text { [18] } \\
\text { India }\end{array}$ & $\begin{array}{l}\text { Experimental, in vivo } \\
\text { intergroup split mouth, } \\
\text { randomized clinical trial }\end{array}$ & 10 & $\begin{array}{l}\text { Group 1: Distilled water } \\
\text { Group 2: Propolis extract } \\
\text { Group 3: Aloe vera extract }\end{array}$ & $\begin{array}{l}\text { Antimicrobial: } \\
\downarrow \text { Bacterial counts } \\
\text { Disinfection }\end{array}$ \\
\hline
\end{tabular}


Table 3. Cont.

\begin{tabular}{|c|c|c|c|c|}
\hline Reference & Study Design & $\begin{array}{l}\text { Number of } \\
\text { Patients }\end{array}$ & Intervention & Results \\
\hline $\begin{array}{l}\text { Pradeep et al. (2016) } \\
{[9]} \\
\text { India }\end{array}$ & $\begin{array}{l}\text { Single center, randomized, } \\
\text { longitudinal, triple masked, } \\
\text { interventional study }\end{array}$ & 60 & $\begin{array}{l}\text { Group 1: Placebo } \\
\text { Group 2: Aloe vera gel }\end{array}$ & $\begin{array}{c}\text { Chronic periodontitis: } \\
\downarrow \text { Plaque index } \\
\downarrow \text { Modified sulcus bleeding index } \\
\downarrow \text { Probing depth } \\
\uparrow \text { Clinical attachment level } \\
\text { Patients with type } 2 \text { diabetes and chronic } \\
\text { periodontitis }\end{array}$ \\
\hline $\begin{array}{l}\text { Rahmani et al. (2014) } \\
\text { [27] } \\
\text { Iran } \\
\end{array}$ & $\begin{array}{l}\text { Prospective observational } \\
\text { clinical trial }\end{array}$ & 60 & $\begin{array}{c}\text { Cream of } 0.5 \% \text { Aloe vera juice powder ( } 3 \\
\text { times daily) } \\
6 \text { weeks }\end{array}$ & $\begin{array}{c}\downarrow \text { Chronic anal fissure pain and } \\
\text { hemorrhaging upon defection } \\
\uparrow \text { Wound healing }\end{array}$ \\
\hline $\begin{array}{l}\text { Sahebjamee et al. } \\
\text { (2015) [19] } \\
\text { Iran }\end{array}$ & $\begin{array}{l}\text { Triple-blind randomised and } \\
\text { controlled interventional }\end{array}$ & 26 & $\begin{array}{l}\text { Group 1: Aloe vera mouthwash } \\
\text { Group 2: benzydamine mouthwash } 0.15 \%\end{array}$ & $\begin{array}{l}\text { Oral mucositis: } \downarrow \text { Severity of } \\
\text { radiation-induced mucositis in patients } \\
\text { with head and neck cancers }\end{array}$ \\
\hline $\begin{array}{l}\text { Sahebnasagh et al. } \\
\text { (2017) [25] } \\
\text { Iran }\end{array}$ & $\begin{array}{l}\text { Double-blind } \\
\text { placebo-controlled trial }\end{array}$ & 20 & $\begin{array}{l}\text { Group 1: Aloe vera gel 3\% } \\
\text { Group 2: Placebo }\end{array}$ & $\begin{array}{c}\text { Proctitis: Improvement of diarrhea, fecal } \\
\text { urgency, clinical presentation total, } \\
\text { Radiation Therapy Oncology Group total } \\
\text { and lifestyle }\end{array}$ \\
\hline $\begin{array}{l}\text { Singh et al. (2016) } \\
\text { [22] } \\
\text { India }\end{array}$ & - & 40 & $\begin{array}{l}\text { Group 1: Aloe vera gel (three times daily) + } \\
\text { physiotherapy } \\
\text { Group 2: Antioxidant capsules (twice daily) } \\
+ \text { physiotherapy } \\
3 \text { months }\end{array}$ & $\begin{array}{c}\text { Oral submucous fibrosis: } \\
\downarrow \text { Burning sensation } \\
\uparrow \text { Mouth opening, cheek flexibility, and } \\
\text { tongue protrusion }\end{array}$ \\
\hline $\begin{array}{l}\text { Størsrud et al. (2015) } \\
\text { [26] } \\
\text { Sweden }\end{array}$ & $\begin{array}{l}\text { Randomized, double-blind, } \\
\text { placebo controlled study }\end{array}$ & 68 & $\begin{array}{l}\text { Group 1: Aloe vera extract (AVH200ß) } \\
\text { Group 2: Placebo } \\
\text { 4 weeks }\end{array}$ & $\begin{array}{l}\text { Irritable bowel syndrome: } \downarrow \text { severity of } \\
\text { the gastrointestinal symptoms }\end{array}$ \\
\hline $\begin{array}{l}\text { Vangipuram et al. } \\
\text { (2016) } \\
{[10]} \\
\text { India }\end{array}$ & Randomized controlled trial & 390 & $\begin{array}{l}\text { Group 1: Aloe vera mouth wash } \\
\text { Group 2: Chlorhexidine }(0.12 \%) \text { mouth wash } \\
\text { Group 3: Placebo }\end{array}$ & $\begin{array}{c}\text { Gingivitis: Aloe vera has equal } \\
\text { effectiveness than chlorhexidine } \\
\downarrow \text { Plaque index and gingival index }\end{array}$ \\
\hline
\end{tabular}


Table 3. Cont

\begin{tabular}{|c|c|c|c|c|}
\hline Reference & Study Design & $\begin{array}{c}\text { Number of } \\
\text { Patients }\end{array}$ & Intervention & Results \\
\hline $\begin{array}{l}\text { Yeturu et al. (2016) } \\
\text { [11] } \\
\text { India }\end{array}$ & $\begin{array}{l}\text { Randomized single-center, } \\
\text { single-blind, parallel group, } \\
\text { controlled trial }\end{array}$ & 85 & $\begin{array}{c}\text { Group 1: Aloe vera mouth wash } \\
\text { Group 2: chlorine dioxide mouth wash } \\
\text { Group 3: chlorhexidine mouth wash } \\
10 \mathrm{~mL} \text { of mouth rinse for } 1 \text { min, twice daily } \\
\text { for } 15 \text { days }\end{array}$ & $\downarrow$ Mean plaque and gingival scores \\
\hline \multicolumn{5}{|c|}{ Skin Protection } \\
\hline $\begin{array}{l}\text { Ahmadloo et al. } \\
\text { (2017) } \\
\text { [57] } \\
\text { Iran }\end{array}$ & $\begin{array}{l}\text { Prospective randomized } \\
\text { controlled clinical trial }\end{array}$ & 100 & $\begin{array}{l}\text { Group 1: Aloe vera gel twice daily } \\
\text { Group 2: control }\end{array}$ & $\begin{array}{c}\text { Dermatitis: No positive effect on } \\
\text { prevalence or severity of radiation } \\
\text { dermatitis }\end{array}$ \\
\hline $\begin{array}{c}\text { Avijgan et al. (2016) } \\
\text { [48] } \\
\text { Iran } \\
\end{array}$ & - & 60 & $\begin{array}{l}\text { Group 1: Aloe vera gel twice daily } \\
\text { Group 2: Conventional treatment } \\
\quad 3 \text { months }\end{array}$ & Ulcers: wound healing \\
\hline $\begin{array}{c}\text { Burusapat et al. (2018) } \\
\text { [53] } \\
\text { Thailand }\end{array}$ & $\begin{array}{l}\text { Double-blind, randomized, } \\
\text { controlled trial }\end{array}$ & 12 & $\begin{array}{l}\text { Group 1: Aloe vera gel } \\
\text { Group 2: Placebo }\end{array}$ & $\begin{array}{c}\uparrow \text { Split-thickness skin graft donor-site } \\
\text { healing } \\
\text { No pain relief }\end{array}$ \\
\hline $\begin{array}{l}\text { Hekmatpou et al. } \\
\text { (2018) } \\
\text { [50] } \\
\text { Iran }\end{array}$ & $\begin{array}{c}\text { Triple-blind randomized clinical } \\
\text { trial }\end{array}$ & 80 & $\begin{array}{c}\text { Group 1: pure Aloe vera gel twice daily } \\
\text { Group 2: Placebo (gel or water and starch) } \\
10 \text { days }\end{array}$ & Ulcers: $\downarrow$ pressure ulcers \\
\hline $\begin{array}{l}\text { Hoopfer et al. (2015) } \\
\text { [58] } \\
\text { Canada }\end{array}$ & $\begin{array}{c}\text { Three-Arm Randomized Phase } \\
\text { III Trial }\end{array}$ & 248 & $\begin{array}{l}\text { Group 1: Aloe vera cream } \\
\text { Group 2: Placebo }\end{array}$ & $\begin{array}{c}\text { No } \downarrow \text { skin reaction severity in breast } \\
\text { cancer radiation therapy }\end{array}$ \\
\hline $\begin{array}{c}\text { Irani and Varaie (2016) } \\
\text { [51] } \\
\text { Iran } \\
\end{array}$ & Randomized clinical trial & 30 & $\begin{array}{c}\text { Burned area: nitrofurazone } 2 \% \\
\text { Symmetry burned area: Aloe vera gel }\end{array}$ & $\begin{array}{l}\text { Burns: Earlier epithelialization and } \\
\text { granulation tissue }\end{array}$ \\
\hline $\begin{array}{l}\text { Molazem et al. (2014) } \\
\text { [52] } \\
\text { Iran }\end{array}$ & $\begin{array}{l}\text { Prospective randomized } \\
\text { double-blind clinical trial }\end{array}$ & 90 & $\begin{array}{l}\text { Group 1: Aloe vera gel } \\
\text { Group 2: dry gauze alone }\end{array}$ & $\uparrow$ Cesarean wound healing \\
\hline
\end{tabular}


Table 3. Cont

\begin{tabular}{|c|c|c|c|c|}
\hline Reference & Study Design & $\begin{array}{l}\text { Number of } \\
\text { Patients }\end{array}$ & Intervention & Results \\
\hline $\begin{array}{c}\text { Tanaka et al. (2015) } \\
\text { [55] } \\
\text { Japan }\end{array}$ & $\begin{array}{l}\text { Randomized, double-blind, } \\
\text { placebo-controlled study }\end{array}$ & 58 & $\begin{array}{c}\text { Group 1: Aloe sterol (5 tablets/daily) } \\
\text { Group 2: Placebo } \\
12 \text { weeks }\end{array}$ & $\downarrow$ Facial wrinkles \\
\hline $\begin{array}{c}\text { Tanaka et al. (2016) } \\
\text { [54] } \\
\text { Japan }\end{array}$ & $\begin{array}{l}\text { Randomized, double-blind, } \\
\text { placebo-controlled study }\end{array}$ & 48 & $\begin{array}{c}\text { Group 1: Aloe sterol (5 tablets/daily) } \\
\text { Group 2: Placebo } \\
12 \text { weeks }\end{array}$ & $\uparrow$ Skin elasticity in photodamaged skin \\
\hline $\begin{array}{c}\text { Tanaka et al. (2016) } \\
\text { [54] } \\
\text { Japan }\end{array}$ & $\begin{array}{l}\text { Randomized, double-blind, } \\
\text { placebo-controlled study }\end{array}$ & 64 & $\begin{array}{c}\text { Group 1: Aloe sterol-supplemented yogurt } \\
\text { Group 2: Placebo }\end{array}$ & $\begin{array}{c}\uparrow \text { Gross elasticity, net elasticity, biological } \\
\text { elasticity, skin fatigue area, collagen } \\
\text { content }\end{array}$ \\
\hline \multicolumn{5}{|c|}{ Anticancer Effects } \\
\hline $\begin{array}{l}\text { Damani et al. (2015) } \\
\text { [86] } \\
\text { USA }\end{array}$ & Case report & 1 & Aloe vera eye drops 3 times daily & $\begin{array}{c}\text { Ocular surface squamous neoplasia: } \\
\text { Lesion regressed }\end{array}$ \\
\hline $\begin{array}{c}\text { Koo et al. (2019) } \\
\text { [87] } \\
\text { South Korea }\end{array}$ & Randomized & 40 & $\begin{array}{c}\text { Group 1: Aloe polysaccharide }(600 \mathrm{mg} / \text { day }) \\
\text { Group 2: Propolis }(600 \mathrm{mg} / \text { day }) \\
\text { Group 3: Aloe polysaccharide + propolis } \\
4 \text { weeks } \\
\text { Group 4: Placebo }\end{array}$ & $\begin{array}{c}\text { Cancer: } \\
\uparrow \text { Urinary excretion of benzo(a)pyrene } \\
\quad \text { and cotinine } \\
\downarrow \text { Creatinine, glucose, and total bilirubin } \\
\quad \text { levels } \\
\downarrow \text { Risk of cancer associated with tobacco }\end{array}$ \\
\hline \multicolumn{5}{|c|}{ Antidiabetic Effect } \\
\hline $\begin{array}{l}\text { Alinejad-Mofrad et al. } \\
\text { (2015) [93] } \\
\text { Iran }\end{array}$ & $\begin{array}{l}\text { Double blind randomized } \\
\text { controlled trial } \\
\text { Pre-diabetes }\end{array}$ & 72 & $\begin{array}{c}\text { Group 1: Placebo } \\
\text { Group 2: Aloe vera } 300 \mathrm{mg} / \text { twice day (AL300) } \\
\text { Group 3: Aloe vera } 500 \mathrm{mg} / \text { twice day (AL500) } \\
4 \text { and } 8 \text { weeks }\end{array}$ & $\begin{array}{l}\text { Diabetes: } \\
\downarrow \text { Fasting blood glucose (AL300, } 4 \text { weeks) }\end{array}$ \\
\hline \multicolumn{5}{|c|}{ Antioxidant Properties } \\
\hline $\begin{array}{l}\text { Prueksrisakul et al. } \\
\text { (2015) [98] } \\
\text { Thailand }\end{array}$ & - & 53 & $\begin{array}{l}\text { Aloe vera gel extract daily } \\
14 \text { days }\end{array}$ & $\begin{array}{c}\text { Antioxidant: } \\
\uparrow \text { Plasma total antioxidant capacity }\end{array}$ \\
\hline
\end{tabular}


Table 3. Cont.

\begin{tabular}{|c|c|c|c|c|}
\hline Reference & Study Design & $\begin{array}{l}\text { Number of } \\
\text { Patients }\end{array}$ & Intervention & Results \\
\hline \multicolumn{5}{|c|}{ Cardioprotective Effect } \\
\hline $\begin{array}{l}\text { Alinejad-Mofrad et al. } \\
\text { (2015) [93] } \\
\text { Iran }\end{array}$ & $\begin{array}{l}\text { Double blind randomized } \\
\text { controlled trial } \\
\text { Pre-diabetes }\end{array}$ & 72 & $\begin{array}{c}\text { Group 1: Placebo } \\
\text { Group 2: Aloe vera } 300 \mathrm{mg} / \mathrm{twice} \text { day (AL300) } \\
\text { Group 3: Aloe vera } 500 \mathrm{mg} / \mathrm{twice} \text { day (AL500) } \\
4 \text { and } 8 \text { weeks }\end{array}$ & $\begin{array}{c}\downarrow \text { HbA1C (AL300, } 8 \text { weeks) } \\
\downarrow \text { Total cholesterol (AL500, } 8 \text { weeks) } \\
\downarrow \text { LDL-C (AL500, } 8 \text { weeks) } \\
\downarrow \text { Triglyceride level (AL500, } 4 \text { weeks) }\end{array}$ \\
\hline \multicolumn{5}{|c|}{ Antimicrobial and Prebiotic Activity } \\
\hline $\begin{array}{l}\text { Prueksrisakul et al. } \\
\text { (2015) [98] } \\
\text { Thailand }\end{array}$ & - & 53 & $\begin{array}{l}\text { Aloe vera gel extract daily } \\
14 \text { days }\end{array}$ & $\begin{array}{l}\text { Antimicrobial: } \\
\downarrow \text { Lactobacillus spp. }\end{array}$ \\
\hline
\end{tabular}


Author Contributions: All authors contributed to the conceptualization, investigation, supervision, and writing of the manuscript. All authors have read and agreed to the published version of the manuscript.

Funding: This research received no external funding.

Conflicts of Interest: The authors declare no conflict of interest.

\section{References}

1. Surjushe, A.; Vasani, R.; Saple, D.G. Aloe vera: A short review. Indian J. Dermatol. 2008, 53, 163-166. [CrossRef]

2. Malik, I.; Zarnigar, H.N. Aloe vera-A Review of its Clinical Effectiveness. Int. Res. J. Phar. 2003, 4, 75-79. [CrossRef]

3. Maan, A.A.; Nazir, A.; Khan, M.K.I.; Ahmad, T.; Zia, R.; Murid, M.; Abrar, M. The therapeutic properties and applications of Aloe vera: A review. J. Herb. Med. 2018, 12, 1-10. [CrossRef]

4. Sholehvar, F.; Mehrabani, D.; Yaghmaei, P.; Vahdati, A. The effect of Aloe vera gel on viability of dental pulp stem cells. Dent. Traumatol. 2016, 32, 390-396. [CrossRef]

5. Lin, H.; Honglang, L.; Weifeng, L.; Junmin, C.; Jiantao, Y.; Junjing, G. The mechanism of alopolysaccharide protecting ulceralive colitis. Bio. Pharm. 2017, 88, 145-150. [CrossRef]

6. Songsiripradubboon, S.; Kladkaew, S.; Trairatvorakul, C.; Sangvanich, P.; Soontornvipart, K.; Banlunara, W.; Thunyakitpisal, P. Stimulation of dentin regeneration by using acemannan in teeth with lipopolysaccharide-induced pulp inflammation. J. Endod. 2017, 43, 1097-1103. [CrossRef]

7. Nejaim, Y.; Silva, A.I.; Vasconcelos, T.V.; Silva, E.J.; de Almeida, S.M. Evaluation of radioprotective effect of Aloe vera and zinc/copper compounds against salivary dysfunction in irradiated rats. J. Oral Sci. 2014, 56, 191-194. [CrossRef]

8. Kumar, G.R.; Devanand, G.; John, B.D.; Ankit, Y.; Khursheed, O.; Sumit, M. Preliminary antiplaque efficacy of Aloe vera mouthwash on 4 day plaque re-growth model: Randomized control trial. Ethiop. J. Health Sci. 2014, 24, 139-144. [CrossRef]

9. Pradeep, A.R.; Garg, V.; Raju, A.; Singh, P. Adjunctive local delivery of Aloe vera gel in patients with type 2 diabetes and chronic periodontitis: A randomized, controlled clinical trial. J. Periodontol. 2016, 87, 268-274. [CrossRef]

10. Vangipuram, S.; Jha, A.; Bhashyam, M. Comparative efficacy of Aloe vera mouthwash and chlorhexidine on periodontal health: A randomized controlled trial. J. Clin. Exp. Dent. 2016, 8, e442. [CrossRef]

11. Yeturu, S.K.; Acharya, S.; Urala, A.S.; Pentapati, K.C. Effect of Aloe vera, chlorine dioxide, and chlorhexidine mouth rinses on plaque and gingivitis: A randomized controlled trial. J. Oral Bio. Craniofac. Res. 2016, 6, 55-59. [CrossRef] [PubMed]

12. Moghaddam, A.A.; Radafshar, G.; Jahandideh, Y.; Kakaei, N. Clinical evaluation of effects of local application of Aloe vera gel as an adjunct to scaling and root planning in patients with chronic periodontitis. J. Dent. 2017, 18, 165-172.

13. Ipshita, S.; Kurian, I.G.; Dileep, P.; Kumar, S.; Singh, P.; Pradeep, A.R. One percent alendronate and Aloe vera gel local host modulating agents in chronic periodontitis patients with class II furcation defects: A randomized, controlled clinical trial. J. Investig. Clin. Dent. 2018, 9, e12334. [CrossRef]

14. Kurian, I.G.; Dileep, P.; Ipshita, S.; Pradeep, A.R. Comparative evaluation of subgingivally-delivered $1 \%$ metformin and Aloe vera gel in the treatment of intrabony defects in chronic periodontitis patients: A randomized, controlled clinical trial. J. Investig. Clin. Dent. 2018, 9, e12324. [CrossRef]

15. Fallahi, H.R.; Hamadzade, H.; Nezhad, A.M.; Zandian, D.; Taghizadeh, M. Effect of Aloe vera mouthwash on postoperative complications after impacted third molar surgery: A randomized, double-blind clinical trial. J. Oral Maxillofac. Surg. Med. Path. 2016, 28, 392-396. [CrossRef]

16. Kalra, M.; Garg, N.; Rallan, M.; Pathivada, L.; Yeluri, R. Comparative evaluation of fresh Aloe barbadensis plant extract and mineral trioxide aggregate as pulpotomy agents in primary molars: A 12-month follow-up study. Contemp. Clin. Dent. 2017, 8, 106-111.

17. Nimma, V.L.; Talla, H.V.; Bairi, J.K.; Gopaldas, M.; Bathula, H.; Vangdoth, S. Holistic healing through herbs: Effectiveness of Aloe vera on post extraction socket healing. J. Clin. Diagn. Res. 2017, 11, 83-86. [CrossRef]

18. Prabhakar, A.R.; Karuna, Y.M.; Yavagal, C.; Deepak, B.M. Cavity disinfection in minimally invasive dentistry-comparative evaluation of Aloe vera and propolis: A randomized clinical trial. Contemp. Clin. Dent. 2015, 6, S24-S31. [CrossRef] 
19. Sahebjamee, M.; Mansourian, A.; Mohammad, M.H.; Zadeh, M.T.; Bekhradi, R.; Kazemian, A.; Doroudgar, K. Comparative efficacy of Aloe vera and benzydamine mouthwashes on radiation-induced oral mucositis: A triple-blind, randomised, controlled clinical trial. Oral Health Prev. Dent. 2015, 13, 309-315.

20. Mansouri, P.; Haghighi, M.; Beheshtipour, N.; Ramzi, M. The effect of Aloe vera solution on chemotherapy-induced stomatitis in clients with lymphoma and leukemia: A randomized controlled clinical trial. Int. J. Community Nurs. Midwifery 2016, 4, 119-126.

21. Anuradha, A.; Patil, B.; Asha, V.R. Evaluation of efficacy of Aloe vera in the treatment of oral submucous fibrosis-a clinical study. J. Oral Path. Med. 2017, 46, 50-55. [CrossRef] [PubMed]

22. Singh, N.; Hebbale, M.; Mhapuskar, A.; Ul, S.N.; Thopte, S.; Singh, S. Effectiveness of Aloe vera and Antioxidant along with Physiotherapy in the Management of Oral Submucous Fibrosis. J. Contemp. Dent. Pract. 2016, 17, 78-84. [CrossRef] [PubMed]

23. Panahi, Y.; Khedmat, H.; Valizadegan, G.; Mohtashami, R.; Sahebkar, A. Efficacy and safety of Aloe vera syrup for the treatment of gastroesophageal reflux disease: A pilot randomized positive-controlled trial. J. Tradit. Chin. Med. 2015, 35, 632-636. [CrossRef]

24. Park, C.H.; Son, H.U.; Yoo, C.Y.; Lee, S.H. Low molecular-weight gel fraction of Aloe vera exhibits gastroprotection by inducing matrix metalloproteinase- 9 inhibitory activity in alcohol-induced acute gastric lesion tissues. Pharm. Biol. 2017, 55, 2110-2115. [CrossRef] [PubMed]

25. Sahebnasagh, A.; Ghasemi, A.; Akbari, J.; Alipour, A.; Lashkardoost, H.; Ala, S.; Salehifar, E. Successful treatment of acute radiation proctitis with Aloe vera: A preliminary randomized controlled clinical trial. J. Altern. Complement. Med. 2017, 23, 858-865. [CrossRef]

26. Størsrud, S.; Pontén, I.; Simrén, M. A pilot study of the effect of Aloe barbadensis Mill. extract $\left(\mathrm{AVH} 200^{\circledR}\right)$ in patients with irritable bowel syndrome: A randomized, double-blind, placebo-controlled study. J. Gastrointestin. Liver Dis. 2015, 24, 275-280. [PubMed]

27. Rahmani, N.; Khademloo, M.; Vosoughi, K.; Assadpour, S. Effects of Aloe vera cream on chronic anal fissure pain, wound healing and hemorrhaging upon defection: A prospective double blind clinical trial. Eur. Rev. Med. Pharmacol. Sci. 2014, 18, 1078-1084.

28. Moriyama, M.; Moriyama, H.; Uda, J.; Kubo, H.; Nakajima, Y.; Goto, A.; Hayakawa, T. Beneficial effects of the genus Aloe on wound healing, cell proliferation, and differentiation of epidermal keratinocytes. PLoS ONE 2016, 11, e0164799. [CrossRef]

29. Hormozi, M.; Assaei, R.; Boroujeni, M.B. The effect of Aloe vera on the expression of wound healing factors (TGF $\beta 1$ and bFGF) in mouse embryonic fibroblast cell: In vitro study. Biomed. Pharm. 2017, 88, 610-616. [CrossRef]

30. Negahdari, S.; Galehdari, H.; Kesmati, M.; Rezaie, A.; Shariati, G. Wound healing activity of extracts and formulations of Aloe vera, henna, adiantum capillus-veneris, and myrrh on mouse dermal fibroblast cells. Int. J. Prevent. Med. 2017, 8, 18.

31. Teplicki, E.; Ma, Q.; Castillo, D.E.; Zarei, M.; Hustad, A.P.; Chen, J.; Li, J. The Effects of Aloe vera on Wound Healing in Cell Proliferation, Migration, and Viability. Wounds 2018, 30, 263-268. [PubMed]

32. De Oliveira, A.C.L.; Tabrez, S.; Shakil, S.; Khan, M.I.; Asghar, M.N.; Matias, B.D.; de Carvalho, R.M. Mutagenic, antioxidant and wound healing properties of Aloe vera. J. Ethnopharmacol. 2018, 227, 191-197.

33. Curto, E.M.; Labelle, A.; Chandler, H.L. Aloe vera: An in vitro study of effects on corneal wound closure and collagenase activity. Vet. Ophthamol. 2014, 17, 403-410. [CrossRef] [PubMed]

34. Liu, F.W.; Liu, F.C.; Wang, Y.R.; Tsai, H.I.; Yu, H.P. Aloin protects skin fibroblasts from heat stress-induced oxidative stress damage by regulating the oxidative defense system. PLoS ONE 2015, 10, e0143528. [CrossRef] [PubMed]

35. Wahedi, H.M.; Jeong, M.; Chae, J.K.; Do, S.G.; Yoon, H.; Kim, S.Y. Aloesin from Aloe vera accelerates skin wound healing by modulating MAPK/Rho and Smad signaling pathways in vitro and in vivo. Phytomedicine 2017, 28, 19-26. [CrossRef] [PubMed]

36. Brandão, M.L.; Reis, P.R.M.; Araújo, L.A.D.; Araújo, A.C.V.; Santos, M.H.D.A.S.; Miguel, M.P. Evaluation of wound healing treated with latex derived from rubber trees and Aloe vera extract in rats. Acta Cir. Bras. 2016, 31, 570-577. [CrossRef]

37. Oryan, A.; Mohammadalipour, A.; Moshiri, A.; Tabandeh, M.R. Topical application of Aloe vera accelerated wound healing, modeling, and remodeling: An experimental study. Annals Plast. Surg. 2016, 77, 37-46. [CrossRef] 
38. Takzaree, N.; Hadjiakhondi, A.; Hassanzadeh, G.; Rouini, M.R.; Manayi, A.; Zolbin, M.M. Transforming growth factor- $\beta$ (TGF- $\beta$ ) activation in cutaneous wounds after topical application of Aloe vera gel. Can. J. Physiol. Pharm. 2016, 94, 1285-1290. [CrossRef]

39. Yos Adi Prakoso, K. The Effects of Aloe vera Cream on the Expression of CD4+ and CD8+ Lymphocytes in Skin Wound Healing. J. Trop. Med. 2018, 2018, 6218303.

40. Sari, Y.; Purnawan, I.; Kurniawan, D.W.; Sutrisna, E. A comparative study of the effects of Nigella sativa oil gel and Aloe vera gel on wound healing in diabetic rats. J. Evid. Based Integr. Med. 2018, 23. [CrossRef]

41. Yao, R.; Tanaka, M.; Misawa, E.; Saito, M.; Nabeshima, K.; Yamauchi, K.; Furukawa, F. Daily Ingestion of Aloe vera Gel Powder Containing Aloe Sterols Prevents Skin Photoaging in OVX Hairless Mice. J. Food Sci. 2016, 81, 2849-2857. [CrossRef]

42. Saito, M.; Tanaka, M.; Misawa, E.; Yao, R.; Nabeshima, K.; Yamauchi, K.; Furukawa, F. Oral administration of Aloe vera gel powder prevents UVB-induced decrease in skin elasticity via suppression of overexpression of MMPs in hairless mice. Biosci. Biotech. Biochem. 2016, 80, 1416-1424. [CrossRef]

43. Misawa, E.; Tanaka, M.; Saito, M.; Nabeshima, K.; Yao, R.; Yamauchi, K.; Furukawa, F. Protective effects of Aloe sterols against UVB-induced photoaging in hairless mice. Photodermatol. Photoimmunomol. Photomed. 2017, 33, 101-111. [CrossRef] [PubMed]

44. Bala, S.; Chugh, N.A.; Bansal, S.C.; Garg, M.L.; Koul, A. Protective role of Aloe vera against X-ray induced testicular dysfunction. Andrologia 2017, 49, 12697. [CrossRef] [PubMed]

45. Bala, S.; Chugh, N.A.; Bansal, S.C.; Garg, M.L.; Koul, A. Radiomodulatory effects of Aloe vera on hepatic and renal tissues of X-ray irradiated mice. Mut. Res. 2018, 811, 1-15. [CrossRef] [PubMed]

46. Lin, L.X.; Wang, P.; Wang, Y.T.; Huang, Y.; Jiang, L.; Wang, X.M. Aloe vera and Vitis vinifera improve wound healing in an in vivo rat burn wound model. Mol. Med. Rep. 2016, 13, 1070-1076. [CrossRef] [PubMed]

47. Rodrigues, D.; Viotto, A.C.; Checchia, R.; Gomide, A.; Severino, D.; Itri, R.; Martins, W.K. Mechanism of Aloe vera extract protection against UVA: Shelter of lysosomal membrane avoids photodamage. Photochem. Photobiol. Sci. 2016, 15, 334-350. [CrossRef] [PubMed]

48. Avijgan, M.; Kamran, A.; Abedini, A. Effectiveness of Aloe vera gel in chronic ulcers in comparison with conventional treatments. Iran. J. Med. Sci. 2016, 41, S30. [PubMed]

49. Leng, H.; Pu, L.; Xu, L.; Shi, X.; Ji, J.; Chen, K. Effects of Aloe polysaccharide, a polysaccharide extracted from Aloe vera, on TNF- $\alpha$-induced HaCaT cell proliferation and the underlying mechanism in psoriasis. Mol. Med. Rep. 2018, 18, 3537-3543. [CrossRef] [PubMed]

50. Hekmatpou, D.; Mehrabi, F.; Rahzani, K.; Aminiyan, A. The effect of Aloe vera gel on prevention of pressure ulcers in patients hospitalized in the orthopedic wards: A randomized triple-blind clinical trial. BMC Complement. Altern. Med. 2018, 18, 1-11. [CrossRef]

51. Irani, P.S.; Varaie, S. Comparison of the effect of Aloe vera Gel and Nitrofurazone $2 \%$ on epithelialization and granulation tissue formation regarding superficial second-degree burns. Iran. J. Med. Sci. 2016, 41, S3. [PubMed]

52. Molazem, Z.; Mohseni, F.; Younesi, M.; Keshavarzi, S. Aloe vera gel and cesarean wound healing; a randomized controlled clinical trial. Global J. Health Sci. 2015, 7, 203. [CrossRef] [PubMed]

53. Burusapat, C.; Supawan, M.; Pruksapong, C.; Pitiseree, A.; Suwantemee, C. Topical Aloe vera gel for accelerated wound healing of split-thickness skin graft donor sites: A double-blind, randomized, controlled trial and systematic review. Plast. Reconstr. Surg. 2018, 142, 217-226. [CrossRef] [PubMed]

54. Tanaka, M.; Yamamoto, Y.; Misawa, E.; Nabeshima, K.; Saito, M.; Yamauchi, K.; Furukawa, F. Aloe sterol supplementation improves skin elasticity in Japanese men with sunlight-exposed skin: A 12-week double-blind, randomized controlled trial. Clin. Cosmet. Invest. Dermat. 2016, 9, 435-442. [CrossRef] [PubMed]

55. Tanaka, M.; Misawa, E.; Yamauchi, K.; Abe, F.; Ishizaki, C. Effects of plant sterols derived from Aloe vera gel on human dermal fibroblasts in vitro and on skin condition in Japanese women. Clinical. Cosmet. Invest. Dermat. 2015, 8, 95-104. [CrossRef] [PubMed]

56. Tanaka, M.; Yamamoto, Y.; Misawa, E.; Nabeshima, K.; Saito, M.; Yamauchi, K.; Furukawa, F. Effects of aloe sterol supplementation on skin elasticity, hydration, and collagen score: A 12-week double-blind, randomized, controlled trial. Skin Pharmacol. Physiol. 2016, 29, 309-317. [CrossRef] 
57. Ahmadloo, N.; Kadkhodaei, B.; Omidvari, S.; Mosalaei, A.; Ansari, M.; Nasrollahi, H.; Mohammadianpanah, M. Lack of prophylactic effects of Aloe vera gel on radiation induced dermatitis in breast cancer patients. Asian Pac. J. Cancer Prev. 2017, 18, 1139-1143.

58. Hoopfer, D.; Holloway, C.; Gabos, Z.; Alidrisi, M.; Chafe, S.; Krause, B.; Hanson, J. Three-arm randomized phase III trial: Quality Aloe and placebo cream versus powder as skin treatment during breast cancer radiation therapy. Clin. Breast Cancer 2015, 15, 181-190. [CrossRef]

59. Ma, Y.; Tang, T.; Sheng, L.; Wang, Z.; Tao, H.; Zhang, Q.; Qi, Z. Aloin suppresses lipopolysaccharide-induced inflammation by inhibiting JAK1-STAT1/3 activation and ROS production in RAW264. 7 cells. Int. J. Mol. Med. 2018, 42, 1925-1934.

60. Jiang, K.; Guo, S.; Yang, C.; Yang, J.; Chen, Y.; Shaukat, A.; Deng, G. Barbaloin protects against lipopolysaccharide (LPS)-induced acute lung injury by inhibiting the ROS-mediated PI3K/AKT/NF- $\mathrm{B}$ pathway. Int. Immunopharm. 2018, 64, 140-150. [CrossRef]

61. Li, C.Y.; Suzuki, K.; Hung, Y.L.; Yang, M.S.; Yu, C.P.; Lin, S.P.; Fang, S.H. Aloe metabolites prevent LPS-induced sepsis and inflammatory response by inhibiting mitogen-activated protein kinase activation. Am. J. Chin. Med. 2017, 45, 847-861. [CrossRef]

62. Thunyakitpisal, P.; Ruangpornvisuti, V.; Kengkwasing, P.; Chokboribal, J.; Sangvanich, P. Acemannan increases NF-kB/DNA binding and IL-6/-8 expression by selectively binding Toll-like receptor-5 in human gingival fibroblasts. Carb. Polymers 2017, 161, 149-157. [CrossRef] [PubMed]

63. Na, H.S.; Song, Y.R.; Kim, S.; Heo, J.Y.; Chung, H.Y.; Chung, J. Aloin Inhibits Interleukin (IL)-1 $\beta$ - Stimulated IL-8 Production in KB Cells. J. Periodontol. 2016, 87, 108-115. [CrossRef] [PubMed]

64. Ahluwalia, B.; Magnusson, M.K.; Isaksson, S.; Larsson, F.; Öhman, L. Effects of Aloe barbadensis Mill. extract $\left(\mathrm{AVH} 200{ }^{\circledR}\right)$ on human blood T cell activity in vitro. J Ethnopharm. 2016, 179, 301-309. [CrossRef] [PubMed]

65. Werawatganon, D.; Linlawan, S.; Thanapirom, K.; Somanawat, K.; Klaikeaw, N.; Rerknimitr, R.; Siriviriyakul, P. Aloe vera attenuated liver injury in mice with acetaminophen-induced hepatitis. BMC Complement. Altern. Med. 2014, 14, 229. [CrossRef] [PubMed]

66. Capes-Davis, A.; Theodosopoulos, G.; Atkin, I.; Drexler, H.G.; Kohara, A.; MacLeod, R.A.; Freshney, R.I. Check your cultures! A list of cross-contaminated or misidentified cell lines. Int. J. Cancer 2010, 127, 1-8. [CrossRef]

67. Holliday, D.L.; Speirs, V. Choosing the right cell line for breast cancer research. Breast Cancer Res. 2011, 13, 215. [CrossRef]

68. Hussain, A.; Sharma, C.; Saniyah, K.; Kruti, S.; Shafiul, H. Aloe vera inhibits proliferation of human breast and cervical cancer cells and acts synergistically with cisplatin. Asian Pac. J. Cancer Prev. 2015, 16, 2939-2946. [CrossRef]

69. Luo, J.; Yuan, Y.; Chang, P.; Li, D.; Liu, Z.; Qu, Y. Combination of aloe-emodin with radiation enhances radiation effects and improves differentiation in human cervical cancer cells. Mol. Med. Rep. 2014, 10, 731-736. [CrossRef]

70. Chen, Q.; Tian, S.; Zhu, J.; Li, K.T.; Yu, T.H.; Yu, L.H.; Bai, D.Q. Exploring a novel target treatment on breast cancer: Aloe-emodin mediated photodynamic therapy induced cell apoptosis and inhibited cell metastasis. Anticancer Agents Med. Chem. 2016, 16, 763-770. [CrossRef]

71. Tseng, H.S.; Wang, Y.F.; Tzeng, Y.M.; Chen, D.R.; Liao, Y.F.; Chiu, H.Y.; Hsieh, W.T. Aloe-emodin enhances tamoxifen cytotoxicity by suppressing Ras/ERK and PI3K/mTOR in breast cancer cells. Am. J. Chin. Med. 2017, 45, 337-350. [CrossRef] [PubMed]

72. Trybus, W.; Krol, T.; Trybus, E.; Stachurska, A.; Kopacz-Bednarska, A.; Krol, G. Induction of mitotic catastrophe in human cervical cancer cells after administration of aloe-emodin. Anticancer Res. 2018, 38, 2037-2044. [PubMed]

73. Shirali, S.; Barari, A.; Hosseini, S.A.; Khodadi, E. Effects of six weeks endurance training and Aloe vera supplementation on COX-2 and VEGF levels in mice with breast cancer. Asian Pac. J. Cancer Prev. 2017, 18, 31-36. [PubMed]

74. Zhang, L.Q.; Lv, R.W.; Qu, X.D.; Chen, X.J.; Lu, H.S.; Wang, Y. Aloesin Suppresses Cell Growth and Metastasis in Ovarian Cancer SKOV3 Cells through the Inhibition of the MAPK Signaling Pathway. Anal. Cell Pathol. 2017, 2017. [CrossRef] [PubMed] 
75. Liu, Y.Q.; Meng, P.S.; Zhang, H.C.; Liu, X.; Wang, M.X.; Cao, W.W.; Zhang, Z.G. Inhibitory effect of aloe emodin mediated photodynamic therapy on human oral mucosa carcinoma in vitro and in vivo. Biomed. Pharmacother. 2018, 97, 697-707. [CrossRef]

76. Chang, X.; Zhao, J.; Tian, F.; Jiang, Y.; Lu, J.; Ma, J.; Liu, K. Aloe-emodin suppresses esophageal cancer cell TE1 proliferation by inhibiting AKT and ERK phosphorylation. Oncol. Lett. 2016, 12, 2232-2238. [CrossRef]

77. Xu, C.; Xu, F. Radio sensitizing effect of Aloe polysaccharide on pancreatic cancer bxpc-3 cells. Pak. J. Pharm. Sci. 2016, 29, 1123-1126.

78. Rawla, P.; Sunkara, T.; Barsouk, A. Epidemiology of colorectal cancer: Incidence, mortality, survival, and risk factors. Prz. Gastroenterol. 2019, 14, 89-103. [CrossRef] [PubMed]

79. Chen, Q.; Li, K.T.; Tian, S.; Yu, T.H.; Yu, L.H.; Lin, H.D.; Bai, D.Q. Photodynamic Therapy Mediated by Aloe-Emodin Inhibited Angiogenesis and Cell Metastasis Through Activating MAPK Signaling Pathway on HUVECs. Technol. Cancer Re. Treat. 2018, 17. [CrossRef]

80. Chihara, T.; Shimpo, K.; Kaneko, T.; Beppu, H.; Higashiguchi, T.; Sonoda, S.; Abe, F. Dietary Aloe vera gel powder and extract inhibit azoxymethane-induced colorectal aberrant crypt foci in mice fed a high-fat diet. Asian Pac. J. Cancer Prev. 2015, 16, 683-687. [CrossRef]

81. Ottaviani, G.; Jaffe, N. The epidemiology of osteosarcoma. Cancer Treat. Res. 2009, 152, 3-13. [PubMed]

82. Li, K.T.; Chen, Q.; Wang, D.W.; Duan, Q.Q.; Tian, S.; He, J.W.; Bai, D.Q. Mitochondrial pathway and endoplasmic reticulum stress participate in the photosensitizing effectiveness of AE-PDT in MG 63 cells. Cancer Med. 2016, 5, 3186-3193. [CrossRef] [PubMed]

83. Tu, P.; Huang, Q.; Ou, Y.; Du, X.; Li, K.; Tao, Y.; Yin, H. Aloe-emodin-mediated photodynamic therapy induces autophagy and apoptosis in human osteosarcoma cell line MG-63 through the ROS/JNK signaling pathway. Oncol. Rep. 2016, 35, 3209-3215. [CrossRef] [PubMed]

84. Ali, Z.; Yousaf, N.; Larkin, J. Melanoma epidemiology, biology and prognosis. EJC Suppl. 2013, 11, 81-91. [CrossRef] [PubMed]

85. Tabolacci, C.; Cordella, M.; Turcano, L.; Rossi, S.; Lentini, A.; Mariotti, S.; De Maria, R. Aloe-emodin exerts a potent anticancer and immunomodulatory activity on BRAF-mutated human melanoma cells. Eur. J. Pharmacol. 2015, 762, 283-292. [CrossRef] [PubMed]

86. Damani, M.R.; Shah, A.R.; Karp, C.L.; Orlin, S.E. Treatment of ocular surface squamous neoplasia with topical Aloe vera drops. Cornea 2015, 34, 87-89. [CrossRef] [PubMed]

87. Koo, H.J.; Lee, K.R.; Kim, H.S.; Lee, B.M. Detoxification effects of Aloe polysaccharide and propolis on the urinary excretion of metabolites in smokers. Food Chem. Toxicol. 2019, 130, 99-108. [CrossRef]

88. Noor, A.; Gunasekaran, S.; Vijayalakshmi, M.A. Improvement of insulin secretion and pancreatic $\beta$-cell function in streptozotocin-induced diabetic rats treated with Aloe vera extract. Pharmacogn. Res. 2017, 9, 99. [CrossRef]

89. Arora, M.K.; Sarup, Y.; Tomar, R.; Singh, M.; Kumar, P. Amelioration of diabetes-induced diabetic nephropathy by Aloe vera: Implication of oxidative stress and hyperlipidemia. J. Diet. Suppl. 2019, 16, 227-244. [CrossRef]

90. Atiba, A.; Wasfy, T.; Abdo, W.; Ghoneim, A.; Kamal, T.; Shukry, M. Aloe vera gel facilitates re-epithelialization of corneal alkali burn in normal and diabetic rats. Clin. Ophthalmol. 2015, 9, 2019-2026.

91. Kim, K.; Chung, M.H.; Park, S.; Cha, J.; Baek, J.H.; Lee, S.Y.; Choi, S.Y. ER stress attenuation by Aloe-derived polysaccharides in the protection of pancreatic $\beta$-cells from free fatty acid-induced lipotoxicity. Biochem. Biophys. Res. Commun. 2018, 500, 797-803. [CrossRef] [PubMed]

92. Alshatwi, A.A.; Subash-Babu, P. Aloe-Emodin Protects RIN-5F (Pancreatic $\beta$-cell) Cell from Glucotoxicity via Regulation of Pro-Inflammatory Cytokine and Downregulation of Bax and Caspase 3. Biomol. Ther. 2016, 24, 49-56. [CrossRef] [PubMed]

93. Alinejad-Mofrad, S.; Foadoddini, M.; Saadatjoo, S.A.; Shayesteh, M. Improvement of glucose and lipid profile status with Aloe vera in pre-diabetic subjects: A randomized controlled-trial. J. Diabetes Metab. Disord. 2015, 14, 22. [CrossRef] [PubMed]

94. Wang, H.C.; Brumaghim, J.L. Polyphenol compounds as antioxidants for disease prevention: Reactive oxygen species scavenging, Enzyme regulation, and metal chelation mechanisms in E. coli and human cells. In Oxidative Stress: Diagnostics, Prevention, and Therapy; American Chemical Society: Washington, DC, USA, 2011; pp. 99-175. 
95. Kumar, S.; Yadav, M.; Yadav, A.; Rohilla, P.; Yadav, J.P. Antiplasmodial potential and quantification of aloin and aloe-emodin in Aloe vera collected from different climatic regions of India. BMC Complement. Altern. Med. 2017, 17, 369. [CrossRef] [PubMed]

96. Cesar, V.; Jozić, I.; Begović, L.; Vuković, T.; Mlinarić, S.; Lepeduš, H.; Žarković, N. Cell-type-specific modulation of hydrogen peroxide cytotoxicity and 4-hydroxynonenal binding to human cellular proteins in vitro by antioxidant Aloe vera extract. Antioxidants 2018, 7, 125. [CrossRef] [PubMed]

97. Sun, Y.N.; Li, W.; Lee, S.H.; Jang, H.D.; Ma, J.Y.; Kim, Y.H. Antioxidant and anti-osteoporotic effects of anthraquinones and related constituents from the aqueous dissolved Aloe exudates. Nat. Prod. Res. 2017, 31, 2810-2813. [CrossRef] [PubMed]

98. Prueksrisakul, T.; Chantarangsu, S.; Thunyakitpisal, P. Effect of daily drinking of Aloe vera gel extract on plasma total antioxidant capacity and oral pathogenic bacteria in healthy volunteer: A short-term study. J. Complement. Integr. Med. 2015, 12, 159-164. [CrossRef]

99. Yang, M.; Li, L.; Heo, S.M.; Soh, Y. Aloe-emodin induces chondrogenic differentiation of ATDC5 cells via MAP kinases and BMP-2 signaling pathways. Biomol. Ther. 2016, 24, 395-401. [CrossRef]

100. Pengjam, Y.; Madhyastha, H.; Madhyastha, R.; Yamaguchi, Y.; Nakajima, Y.; Maruyama, M. NF-kB pathway inhibition by anthrocyclic glycoside aloin is key event in preventing osteoclastogenesis in RAW264. 7 cells. Phytomedicine 2016, 23, 417-428. [CrossRef]

101. Madhyastha, R.; Madhyastha, H.; Pengjam, Y.; Nurrahmah, Q.I.; Nakajima, Y.; Maruyama, M. The pivotal role of microRNA-21 in osteoclastogenesis inhibition by anthracycline glycoside aloin. J. Nat. Med. 2019, 73, 59-66. [CrossRef]

102. Yuksel, Y.; Guven, M.; Kaymaz, B.; Sehitoglu, M.H.; Aras, A.B.; Akman, T.; Cosar, M. Effects of Aloe vera on spinal cord Ischemia-Reperfusion injury of rats. J. Invest. Surg. 2016, 29, 389-398. [CrossRef] [PubMed]

103. Sahin, H.; Yener, A.U.; Karaboga, I.; Sehitoglu, M.H.; Dogu, T.; Altinisik, H.B.; Simsek, T. Protective effect of gel form of gastric gavage applicated Aloe vera on ischemia reperfusion injury in renal and lung tissue. Cell Mol. Biol. 2017, 63, 34-39. [CrossRef] [PubMed]

104. Zhang, P.; Liu, X.; Huang, G.; Bai, C.; Zhang, Z.; Li, H. Barbaloin pretreatment attenuates myocardial ischemia-reperfusion injury via activation of AMPK. Biochem. Biophys. Res. Commun. 2017, 490, 1215-1220. [CrossRef] [PubMed]

105. Esmat, A.Y.; Said, M.M.; Khalil, S.A. Aloin: A natural antitumor anthraquinone glycoside with iron chelating and non-atherogenic activities. Pharm. Biol. 2015, 53, 138-146. [CrossRef] [PubMed]

106. Furkan, M.; Alam, M.T.; Rizvi, A.; Khan, K.; Ali, A.; Naeem, A. Aloe emodin, an anthroquinone from Aloe vera acts as an anti aggregatory agent to the thermally aggregated hemoglobin. Spectrochim. Acta Part A: Mol. Biomol. Spectrosc. 2017, 179, 188-193. [CrossRef]

107. Ji, H.; Liu, Y.; He, F.; An, R.; Du, Z. LC-MS based urinary metabolomics study of the intervention effect of aloe-emodin on hyperlipidemia rats. J. Pharm. Biomed. Anal. 2018, 156, 104-115. [CrossRef]

108. Guven, M.; Gölge, U.H.; Aslan, E.; Sehitoglu, M.H.; Aras, A.B.; Akman, T.; Cosar, M. The effect of Aloe vera on ischemia-Reperfusion injury of sciatic nerve in rats. Biomed. Pharmacother. 2016, 79, 201-207. [CrossRef]

109. Saddiq, A.A.; Al-Ghamdi, H. Aloe vera extract: A novel antimicrobial and antibiofilm against methicillin resistant Staphylococcus aureus strains. Pak. J. Pharm. Sci. 2018, 31, 2123-2130.

110. Jain, S.; Rathod, N.; Nagi, R.; Sur, J.; Laheji, A.; Gupta, N.; Prasad, S. Antibacterial Effect of Aloe vera Gel against Oral Pathogens: An In-vitro Study. J. Clin. Diagn. Res. 2016, 10, 41-44. [CrossRef]

111. Xiang, H.; Cao, F.; Ming, D.; Zheng, Y.; Dong, X.; Zhong, X.; Wang, L. Aloe-emodin inhibits Staphylococcus aureus biofilms and extracellular protein production at the initial adhesion stage of biofilm development. Appl. Microbiol. Biotechnol. 2017, 101, 6671-6681. [CrossRef]

112. Goudarzi, M.; Fazeli, M.; Azad, M.; Seyedjavadi, S.S.; Mousavi, R. Aloe vera gel: Effective therapeutic agent against multidrug-resistant Pseudomonas aeruginosa isolates recovered from burn wound infections. Chemother. Res. Pract. 2015, 2015. [CrossRef] [PubMed]

113. Cataldi, V.; Di Bartolomeo, S.; Di Campli, E.; Nostro, A.; Cellini, L.; Di Giulio, M. In vitro activity of Aloe vera inner gel against microorganisms grown in planktonic and sessile phases. Int. J. Immunopathol. Pharmacol. 2015, 28, 595-602. [CrossRef] [PubMed]

114. Karkare, S.R.; Ahire, N.P.; Khedkar, S.U. Comparative evaluation of antimicrobial activity of hydroalcoholic extract of Aloe vera, garlic, and 5\% sodium hypochlorite as root canal irrigants against Enterococcus faecalis: An in vitro study. J. Indian Soc. Pedod. Prev. Dent. 2015, 33, 274-278. [PubMed] 
115. Arjomandzadegan, M.; Emami, N.; Habibi, G.; Farazi, A.A.; Kahbazi, M.; Sarmadian, H.; Jabbari, M.; Hosseini, H.; Ramezani, M. Antimycobacterial activity assessment of three ethnobotanical plants against Mycobacterium Tuberculosis: An In Vitro study. Int. J. Mycobacteriol. 2016, 1, 108-109. [CrossRef] [PubMed]

116. Rezazadeh, F.; Moshaverinia, M.; Motamedifar, M.; Alyaseri, M. Assessment of Anti HSV-1 Activity of Aloe vera Gel Extract: An In Vitro Study. J. Dent. 2016, 17, 49-54.

117. Sun, Z.; Yu, C.; Wang, W.; Yu, G.; Zhang, T.; Zhang, L.; Zhang, J.; Wei, K. Aloe Polysaccharides Inhibit Influenza A Virus Infection-A Promising Natural Anti-flu. Drug. Front. Microbiol. 2018, 9, 2338. [CrossRef]

118. Kumar, S.; Yadav, A.; Yadav, M.; Yadav, J.P. Effect of climate change on phytochemical diversity, total phenolic content and in vitro antioxidant activity of Aloe vera (L.) Burm.f. BMC Res. Notes 2017, 10, 60. [CrossRef]

119. Gullón, B.; Gullón, P.; Tavaria, F.; Alonso, J.L.; Pintado, M. In vitro assessment of the prebiotic potential of Aloe vera mucilage and its impact on the human microbiota. Food Funct. 2015, 6, 525-531. [CrossRef]

120. Quezada, M.P.; Salinas, C.; Gotteland, M.; Cardemil, L. Acemannan and Fructans from Aloe vera (Aloe barbadensis Miller) Plants as Novel Prebiotics. J. Agric. Food Chem. 2017, 65, 10029-10039. [CrossRef]

121. Asgharzade, S.; Rafieian-Kopaei, M.; Mirzaeian, A.; Reiisi, S.; Salimzadeh, L. Aloe vera toxic effects: Expression of inducible nitric oxide synthase (iNOS) in testis of Wistar rat. Iran. J. Basic Med. Sci. 2015, 18, 967-973.

122. Erhabor, J.O.; Idu, M. Aphrodisiac potentials of the ethanol extract of Aloe barbadensis Mill. root in male Wistar rats. BMC Complement. Altern. Med. 2017, 17, 360. [CrossRef] [PubMed]

123. Behmanesh, M.A.; Najafzadehvarzi, H.; Poormoosavi, S.M. Protective Effect of Aloe vera Extract against Bisphenol A Induced Testicular Toxicity in Wistar Rats. Cell 2018, 20, 278-283.

124. Lee, D.; Kim, H.S.; Shin, E.; Do, S.G.; Lee, C.K.; Kim, Y.M.; Lee, M.B.; Min, K.Y.; Koo, J.; Kim, S.J.; et al. Polysaccharide isolated from Aloe vera gel suppresses ovalbumin-induced food allergy through inhibition of Th2 immunity in mice. Biomed. Pharmacother. 2018, 101, 201-210. [CrossRef]

125. Im, S.A.; Kim, K.H.; Kim, H.S.; Lee, K.H.; Shin, E.; Do, S.G.; Jo, T.H.; Park, Y.I.; Lee, C.K. Processed Aloe vera gel ameliorates cyclophosphamide-induced immunotoxicity. Int. J. Mol. Sci. 2014, 15, 19342-19354. [CrossRef]

126. Iftkhar, A.; Hasan, I.J.; Sarfraz, M.; Jafri, L.; Ashraf, M.A. Nephroprotective Effect of the Leaves of Aloe barbadensis (Aloe vera) against Toxicity Induced by Diclofenac Sodium in Albino Rabbits. West Indian Med. J. 2015, 64, 462-467.

127. Hashiguchi, M.; Suzuki, K.; Kaneko, K.; Nagaoka, I. Effect of aloe-emodin on the proliferation and apoptosis of human synovial MH7A cells; a comparison with methotrexate. Mol. Med. 2017, 15, 4398-4404. [CrossRef] [PubMed]

128. Aro, A.A.; Esquisatto, M.A.; Nishan, U.; Perez, M.O.; Rodrigues, R.A.; Foglio, M.A.; Carvalho, J.E.; Gomes, L.; Vidal Bde, C.; Pimentel, E.R. Effect of Aloe vera application on the content and molecular arrangement of glycosaminoglycans during calcaneal tendon healing. Microsc. Res. Tech. 2014, 77, 964-973. [CrossRef]

129. Shahraki, M.R.; Mirshekari, H.; Sabri, A. Aloe vera Aqueous Extract Effect on Morphine Withdrawal Syndrome in Morphine-Dependent Female Rats. Int. J. High Risks Behav. Addict. 2014, 3, e11358. [CrossRef]

130. Koul, A.; Bala, S.; Yasmeen Arora, N. Aloe vera affects changes induced in pulmonary tissue of mice caused by cigarette smoke inhalation. Environ. Toxicol. 2015, 30, 999-1013. [CrossRef] [PubMed]

131. Wu, J.; Ke, X.; Wang, W.; Zhang, H.; Ma, N.; Fu, W.; Zhao, M.; Gao, X.; Hao, X.; Zhang, Z. Aloe-emodin suppresses hypoxia-induced retinal angiogenesis via inhibition of HIF-1 $\alpha /$ VEGF pathway. Int. J. Biol. Sci. 2016, 12, 1363-1371. [CrossRef]

132. Prakoso, Y.A.; Setiyo Rini, C.; Wirjaatmadja, R. Efficacy of Aloe vera, Ananas comosus, and Sansevieria masoniana Cream on the Skin Wound Infected with MRSA. Adv. Pharmacol. Sci. 2018, 2018, 4670569. [CrossRef] [PubMed]

133. Coelho, F.H.; Salvadori, G.; Rados, P.V.; Magnusson, A.; Danilevicz, C.K.; Meurer, L.; Martins, M.D. Topical Aloe Vera (Aloe barbadensis Miller) Extract Does Not Accelerate the Oral Wound Healing in Rats. Phytother. Res. 2015, 29, 1102-1105. [CrossRef] [PubMed]

134. Tabatabaei, S.R.F.; Ghaderi, S.; Bahrami-Tapehebur, M.; Farbood, Y.; Rashno, M. Aloe vera gel improves behavioral deficits and oxidative status in streptozotocin-induced diabetic rats. Biomed. Pharmacother. 2017, 96, 279-290. [CrossRef] [PubMed]

135. Abdollahnejad, F.; Mosaddegh, M.; Nasoohi, S.; Mirnajafi-Zadeh, J.; Kamalinejad, M.; Faizi, M. Study of Sedative-Hypnotic Effects of Aloe vera L. Aqueous Extract through Behavioral Evaluations and EEG Recording in Rats. Iran. J. Pharm. Res. 2016, 15, 293-300. [PubMed] 
136. Mawarti, H.; Rajin, M.; Asumta, Z. The Effects of Aloe vera on TNF-a Levels, the Percentage of Nk Cells and Th 17 Cells in Rat That Received Izoniazid and Rifampycin. Med. Arch. 2017, 71, 308-311. [CrossRef] [PubMed]

137. Boudreau, M.D.; Olson, G.R.; Tryndyak, V.P.; Bryant, M.S.; Felton, R.P.; Beland, F.A. From the Cover: Aloin, a Component of the Aloe vera Plant Leaf, Induces Pathological Changes and Modulates the Composition of Microbiota in the Large Intestines of F344/N Male Rats. Toxicol. Sci. 2017, 158, 302-318. [CrossRef]

(c)

(C) 2020 by the authors. Licensee MDPI, Basel, Switzerland. This article is an open access article distributed under the terms and conditions of the Creative Commons Attribution (CC BY) license (http://creativecommons.org/licenses/by/4.0/). 